\title{
BAĞIMSIZ İDARİ KURUM OLARAK RTÜK
}

\author{
Refik TİRYAKI'
}

Teknolojinin yaşamın her alanına girişi, insanın özgürlügü sorununu olduğundan daha çetrefil hale getirmiş, temel hak ve özgürlükler alanında yeni sorunlar ve tartışmalar do gurmuştur. Bunun en güzel örneklerinden biri de bu gelişimin devletin işleyişinde ortaya çıkardığı değişimdir. Değişimin boyutu onun niceliğinden çok niteliğjyle ilgilidir. Çünkü teknolojinin bu ölçiudeki değişimi temel hak ve hürriyetler ya da özgürlükler alanı ile idarenin eylemleri ve işlemleri arasındaki sınırı daha geniş, belirsiz ve karmaşık hale getirmiş olmasıdır. Yani bu değişim insan haklarını doğrudan ilgilendirmektedir. Bu nedenle koruma mekanizmalarında genişleme konunun genişlemesi- ve derinleşmenin -ihlâl teorisinin genişlemesiyanında çeşitlenmeler -koruma şemsiyesinin kurumsal olarak genişlemeside ortaya çıkmıştır.

Bilindiği üzere idare ya da daha kapsayıcı bir ifadeyle devlet, özgürlüğe hemen her zaman sınırlayıcı olarak miidahale edendir. Bu aslinda devletin varlık nedeni olan koruma, kollama ve düzenleme işlevinin doğal bir sonucudur. Çïnkü özgürlük teorisi açısından koruma ve kollama amacıyla da yapılsa her düzenleme aynı zamanda bir sınırlamadır. Bu niteliğiyle düzenleyen devlet aynı zamanda sınırlayan da olmaktadır. İşte bu düzenleme bugünỉn dünyasında daha dikkat çekici bir hal almıştır. Çünkü teknolojinin geldiği nokta bizi, klasik özgürlük-idare ilişkisini sorgulamaya ve hatta yeniden kurgulamaya itmektedir. Sonuç olarak da belli alanların klasik idarenin yetki alanından çıkarılmasına ihtiyaç duyulmaktadır.

Bizi özgürlük-idare ilişkisini yeniden kurgulamaya iten nedenlerden birisi de idarenin yirminci yüzyılda kamu hizmetlerinin sunucusu konumundan çekilerek söz konusu alanları serbest piyasa sürecine bırakmış olmasıdır. Özelleştirme denilen bu değişim devletin kamu gícü kullanımının hem boyutunu hem de yoğunluğunu deģiştirmiştir. Bu durumda devlet idaresi aktif olarak müdahale etmek bir yana deyim yerindeyse oyunun

\footnotetext{
' Ankara Üniversitesi Sosyal Bilimler Enstitüsü Kamu (Anayasa-İdare) Hukuku Anabilim Dalı Doktora Ö̌rencisi.
} 
kurallarını tayin eden ve buna riayeti sağlayan konumuna oturmuştur. Bu değişimde konunun aktörlerinin anılan işlevi devlet idaresi ile organik bağı olmayan birimlerin yerine getirmesini istemelerinin büyük etkisi olmuştur. Onların istekleri doğrultusunda ya cla onların dile getirdikleri doğrultuda bir örgütlenme modeli özellikle hassas olarak nitelenen bir çok alandan benimsenmiştir(WADE: 167-8).

$\mathrm{Bu}$ çalışmada biz hassas alanlardan kabul edilen radyo televizyon yayıncılığı sektöründe oyunun kurallarını belirlemek ve ona riayeti sağlamak için oluşturulan Radyo ve Televizyon Üst Kurulu (RTÜK) üzerinde bir inceleme yapacă̆ız. Bu çalışmamızı doğrudan 3984 s. Kanuna özgü̉eme isteğimize rağmen konunun anlam bütünlüğünün sağlanabilmesi ve kurumların ve kurallarm daha rahat anlaşılabilmesi için genel konuları da içerecek şekilde yürüteceğiz. Dolayısıyla bağımsız idari kurum olarak RTUKK incelenirken kurum ve kuralların ele alınmasına öncelikle bağımsız idari otoriteler (kurumlar) açısından daha sonra 3984 s. Kanun açısından yaklaşacağı.

Çalışmamızda ilk olarak terim sorununa, daha sonrada sırasıyla, bizi bağımsız idari bir kưum olarak RTÜK ile baş başa bırakan gelişmelere ve ihtiyaçlara, RTỨ'ün idari sistemimiz içerisinde işgal ettiği yere değineceğiz. Bu çerçevede bağımsız idari kurumların karakteristiklerine ve onun RTUKK özelindeki yansımalarına değinirken son olarak kurumun Anayasal konumunu da idari sistemimiz için geçerli ilkeler bakımından sorgulayaca $y_{1 z}$. Daha sonra denetim yolu olarak siyasi, mali ve idari denetim konularını ele alıp RTÜK'ün işlemlerinin yargısal denetimine değineceğiz. Son olarak da RTUK'ün kanunda sayılan görev ve yetkileri üzerinde sınıflandırılmış kısa açıklamalarından ardından kurum ïzerindeki görüşlerimize yer vereceğiz.

\section{TERİM SORUNU -BÍK ya da BİO-}

Radyo ve Televizyon Üst Kurulu (RTÜK) birçok eserde yabancı dillerdeki terimin (indipendent administrative authority, les autorites administratives independantes) tam karşılığına uygun olarak "bağımsız idari otorite" olarak adlandırılmaktadır. Ileride de görüleceği üzere RTÜK bir kamu hukuku tỉzel kişisidir. Bu niteliğiyle RTUKK, idare hukukunun asli ve yoğun bir süjesidir. Dolayısıyla kamusal alanda idarenin yararlandığı üstünlük ve ayrıcalıklara sahiptir.

Kamu hukukumuzda tüzel kişilerin çeşitleri konusunda kamu kurumları ve kamu idareleri ayrımı yapılmaktaydı (DURAN:1982:78). Kamu idarelerinin en belirgin özelliği Anayasa ile kişilikleri belirlenen bu yapłlarn 
sayılarının yine Anayasa ile smırlandırılmıs olması ve genel niteliklerinin belirlenmiş olması (DURAN:1982:78) iken kamu kurumlarmın en belirgin özellikleri olarak belirli bir hizmetin tüzel kişilik sahibi örgüt tarafından görülmesini sağlamaları ve belirli ve özel görev ve yetki ile donatılıp (DURAN:1982:193) özerkliğe sahip kılınmaları şeklinde belirlenmekteydi. Ancak son dönem idare hukuku kitaplarmda bu tip bir ayrma yer verilmemektedir (GÜNDAY: 2002 ; GÖZÜBÜYÜK-TAN ${ }^{2}$ ). Dolayısıyla böyle bir ayrım yapılmadan RTÜK'ï kamu tüzel kişiliğini haiz kamu kurumlarından kabul etmek mümkündür. Ancak yapılan ayrım çerçevesinde RTÜK ele alındığında onun bir kamu kurumu olarak nitelendirilmesi gerekmektedir. Çünkü RTÜK, tüizel kişiliği Anayasa ile belirlenmiş kamu idareleri arasında yer almamaktadır. Tek başına bu değerlendirme bile RTÜK'ü kamu kurumu olarak nitelememizi mümkün kılmaktadır. Ayrıca RTƯK'ü kamu kurumu olarak nitelememiz bile ileride de görüleceğgi üzere hizmet yerinden yönetimi kuruluşlarından farklı özelliklere sahip olduğu gerçeğini gözardı etmemiz sonucunu doğuramaz. Çünkỉ RTÜK'ün bir hizmeti yürütmesi söz konusu olmayıp bir hizmet alanında kolluk faaliyeti üstlenmesi söz konusudur. Bu çerçevede hizmet yerinden yönetim kuruluşlarından ayrilabildiği gibi kamu hizmetinin asli sunucusu olan kamu idarelerinden ayrilabilmektedir. Bütün bunlara dayalı olarak RTÜK'ün bir kamu kurumu olarak nitelendirilmesi gerekir ${ }^{3}$.

\section{NEDEN BAĞIMSIZ İDARİ KURUM OLARAK RTÜK?}

\section{Genel Olarak}

Bağımsız idari kurumların varlık nedenlerinden biri temel hak ve özgürlükler alanı ile idarenin değişen işlevleri arasında kurulmasına ihtiyaç duyulan yeni ilişkidir. Özellikle radyo ve televizyon alanında bu ihtiyaç açı olarak gözlenir. Nitekim bağımsız idari kurumların faaliyet gösterdiği diğger bir çok alanda(örneğin enerji, rekabet, ulaşım vb. ) esas belirleyici etken liberal ekonomik degerlerin güvence altına alınmasıdır(WADE: 167). Bu nitelikteki bağımsız idari kurumlarm işlevleri sonucunda temel hak ve özgürlükler alanı için olumlu sonuçlar da ortaya çıkmaktadır.

\footnotetext{
${ }^{2}$ Ancak GÖZÜBÜYÜK-TAN böyle bir ayrımı açıkça yapmamış olsalar da " "kamu kurumlan, kamu idareleri gibi türleri Anayasa ile sinirlanmadığ için say ve tür olarak çeşitlilik góstermektedirler" ifadesj ile bu ayrum hala kultanmaktadılar (GÖZÜBUYYUK TAN: 234 )

${ }^{3}$ Benzer bir adłandırma yapan ULUSOY, bağımsız idari otorite terimini Tük hukukunda pek kullanılmadığ özerk kuruluşlar terimini ise hizmet yerinden yönetim kuruluşlarını çă̌grı̧̧ırdığı için benimsemediğini yazmaktadır.
} 
Bu ilişkinin yeniden kurulmasına neden ihtiyaç duyulmuşstur? Bu noktada gerekçelerden ${ }^{4}$ ikisi üzerinde durulabilir; (i) temel hak ve hürriyetler alanında teknolojinin gelişimi sonucu yaşanan değişim ve bu durumun etkileri ve (ii) idarenin belli konularda atıl kalması.

\section{İdarenin Atıl Kalması}

İdarenin atıl kalması argümanı teknolojinin hızlı gelişimine atıf yapmaktadır. Şöyle ki; klasik idari yapıların atıl kalması, teknolojinin gerektirdiği düzenleme ve denetleme faaliyetlerini zamanında ve yeterince yerine getirememelerini ifade eder. İdarenin yavaş işleyen karar alma mekanizmasından bağımsız bir mekanizmaya da bu nedenle ihtiyaç duyulmuştur (THOMPSON: 259). Çünkü zamanın paraya eşdeğer olduğu sermaye piyasalarında ya da iletişim sektöründe veya bireylerin ve hatta belli girişimlerin büyük şirketlerden ya da paralel davranan farklı şirketlerden korunması alanlarında idarenin yeterince çabuk ve etkin olamadı $\breve{g}_{1}$ görüilmüştür.

\section{Teknolojinin Temel Hak ve Hürriyetlerle İlişkisi}

Teknolojinin temel hak ve hürriyetler alam ile ilişkisi, teknolojinin ulaştığı düzeyin temel hak ve hürriyet alanını daha geniş hale getirdiğini ortaya koymaktadır. Nitekim teknoloji, basın özgürlüğünün alanını genişletmiş; ifade özgürliiğünün araçlarını farklılaştırmış ve hatta daha ileri giderek görsel ve işitsel iletişim özgürlügü denilen yeni bir özgürlük alanı doğurmuştur. Teknolojinin bu etkileri sonucunda söz konusu alanların klasik idari yapılar tarafından idare edilmesinde (düzenlenmesi ve denetlenmesinde) zafiyet riski ortaya çıkmış ve buna bağlı olarak üst kurullar oluşturulmuştur.

Bu çerçeveden bakıldı̆̆ında bağımsız idari kurumlar, yeni teknolojilerin temel hak ve özgürlük alanlarının ihlâl tehditlerini ve risklerini etkisiz hale getirmek için kurulmuşlardır(DURAN: 1997: 4).

Ust kurulların ya da bağımsız idari kurumların ortaya çıkışının bir diğer nedeni de bu yapiların düzenleme ve denetleme faaliyetlerinde bulundukları alanlara politikacıların müdahalelerinin asgari düzeye indirilmesi hatta yok edilmesi isteğidir (THOMPSON: 259). Bu istek temel hak ve hürriyetlere

\footnotetext{
${ }^{4}$ Çalışmada ele alınmayan gerekçeler arasında; (i)bazı faaliyetlerin konusunda uzman kişilete gördưrülmesi. (ii) kamu gücünün dağıtılmasına duyulan ihtiyaç ve (iii) çalışanları devlet memurları statüsünde sayılmayacak kurumlar yoluyla memur sayısıyla baş edebilme isteği sayılmaktadır. Brian THOMPSON, Textbook on Constitutional and Administrative Law, $3^{\text {nd }}$ Ed., Blackstone Press Limited, London, 1997, s. 259.
} 
müdahale olgusunun ötesinde ilgili alanların özelliklerinden kaynaklanmaktadır. Nitekim bu kurulların iletişim, medya, ekonomik rekabet, bankacılık, finans vb. sektörleri içeren çalışma alanları duyarlı sektörler olarak kabul edilmekte ve politikacıların müdahalelerinden olabildiğince uzak bulunmaları arzulanmaktadır(ULUSOY: 2000: 46).

\section{RTÜK Özelinde Değerlendirme}

Anlatılanlar çerçevesinde RTÜK'ün neden ortaya çıtığı sorununa değinmek gerekmektedir. Bu noktada kısaca tarihsel gelişime de atıf yapılacaktrr. RTUK'ün faaliyet konusunu oluşturan radyo ve televizyon alanı Türkiye'de ilk olarak özel teşebbüsün konusunu oluşturmuştur. Cumhuriyetin ilk yıllarına denk düşen bu zaman kesiti yerini kısa sürede devlet tekeline bırakmıştır. 1961 Anayasasının yapımı aşamasında dahi süren bu durum konunun devlet tekelinde yüruituilmesi düzenlenmesiyle devam etmiştir. Aynı mantık ve düzenleme 1982 Anayasasının yapımı aşamasında da geçerli olmuştur. Nitekim Anayasanın ilk halinde konu 133. maddede;

"Radyo ve televizyon idareleri ancak devlet eliyle kurulur ve idareleri tarafsiz bir kamu tïzel kişiliği halinde düzenlenir"

şeklinde ifade edilmiştir. Ancak 1980 'li y1lların sonunda özel kişilerce kurulan radyo-televizyonların fiili bir durum oluşturmaları Anayasa'nın değiştirilmesi ihtiyacını doğurmuştur. Bu çerçevede yapılan degişiklikle konu Anayasa'da;

"Radyo ve televizyon istasyonlart kurmak ve işletmek kanunla düzenlenecek şartlar çerçevesinde serbesttir"

şeklinde düzenlenmiştir. İşte bu anayasal durum alanı idare edecek bir idari yapının kurulmasını gerektirmiştir. Yukarıaki anayasal düzenlemenin yapılmasımdan dokuz ay sonra çıkarılan $3984 \mathrm{~s}$. "Radyo ve Televizyonlarm Kuruluş ve Yaymlart Hakkında Kanun"(RG 20. 4. 1994, S. 21911, s. Ivd. ) ile de RTÜK kurulmuştur.

Radyo ve televizyon alanında neden klasik idari şemaya tabî bir idarî kuruluş oluşturulmamıştır? Bunun siyasi ve sosyal şartlarını inceleme dışında tutarsak konunun özgürlük boyutunu kısaca ele almak gerekir. Ancak bu sorunun cevabını vermek için idarenin bu alandaki faaliyetinin niteliğini de sorgulamak gerekir. 
Yukarıda, yeni- teknolojilerin varolan temel hak ve özgürlükleri çeşitli boyutlarda etkilediğine ve yeni özgürlük alanları doğurduğuna değinmiştik. Bunların en bilinenlerinden görsel-işitsel iletişim özgürlüğü ya da radyo ve televizyon alan bir çok boyut ihtiva eder. Birincisi, bu alanda girişimde bulunan özel kisilerin ekonomik özgürlükleri; ikincisi, bu alanın aktif aktörleri olarak faaliyet gösteren kişilerin ifade özgürlüğü: ïçüncüsü bu alanın pasif aktörieri olan bireylerin bilgi edinme ve düsünce özgürlüğ̣ü dür.

İdarenin radyo-televizyon alanındaki ilk rolü bu faaliyati yürütmek olmuştur. Bu nedenle devlet radyo ve televizyon alanına ilk olarak kamu hizmeti yürüten mahiyetinde girmiştir. Bu faaliyet hizmetin sunumunu içerdiği gibi söz konusu özgürlük alanının düzenlenmesi ve denetimini de içermektedir. Ancak yukarıda değginilen fiili durumdan sonra konunun anayasal düzenlemeye kavuşturulması ile idarenin radyo televizyon yayıncılığı alanındaki işlevi ikiye bölünmüştür. Bunların ilki değişen boyutuyla dïzenleme ve denetleme işlevi ki bir idari kuruma burakılmak durumunda kalınmıştır(GÖZÜBÜYÜK-TAN: 289), diğer ise çeşitli nedenlerle vazgeçilemeyen kamu hizmeti sunumudur.

Idarenin temel faaliyet alanlarından kolluk işlemleri "idarenin kamu dïzenini sağlamak ve korumak için giriştiği tüm faaliyetler" şeklinde tanımlanmaktadır(GÜNDAY: 2002: 245). İdarenin kolluk faaliyetinin konusu olarak sağlayıp koruyacağı kamu düzeni dışsaldır. Dışsallıktan kasst, toplumun genel olarak barış, güvenlik ve sağlık içinde yaşaması durumudur(GÍRITLİ-AKGÜNER-BÍLGEN: 740). Dolayısiyla toplumun barış içinde yaşamasında önemli bir etken olan radyo ve televizyon alanında da içsel düzenin sağlanması toplum barışını bozacak eylemlerin engellenmesi için önemlidir. Bu nedenle bu alandaki idari faaliyetin de özel kolluk faaliyeti olarak adlandırılması gerekir(GÜNDAY: 2002: 496).

RTÜK'ïn kurulması konusundaki bir diğer etmen Anayasamızdaki temel hak ve özgürlük rejimidir. Anayasann 26. maddesi düşünceyi açılama ve yayma özgürlüğü kapsamında iletişim özgürlüğüune yer vermiştir. Nitekim maddenin birinci flkrasında konu :

"Herkes, diş̧̈̈nce ve kanaatlerini söz, yazı, resim veya başka yollarla tek basma reva toplu olarak açklama ve yayma hakkma sahiptir. Bu hïrriyet resmi makamlarm müdahalesi olmaksizm haber veya fikir almak va da vermek serbestliğini de kapsar. Bu fikra hükmü radyo, televizyon, sinema veya benzeri yollarla yapilan vaymlarn izin sistemine bağlanmastna engel de ğildir." (abç)

\footnotetext{
${ }^{5}$ Burada düşỉnce ö7giırlüğünün bilgi edinme özgürlügünden daha özcl/(spesilik) olarak öncül yanı vurğctianmak istenmektedir.
} 
şeklinde düzenlenmiştir. Buradaki "haber veya fikir alma ve verme. özgürlüğii" görsel ve işitsel iletişim özgürlügủnün şekli konusunu oluşturan aktif süjelere yöneldiği gibi pasif süjelere de yönelmektedir. Ayrica bu yazım iletişim özgürlìğüunün maddi konusunu oluşturan "haber ve fik(i)r(i)" de kapsamaktadır. Dolayısıyla görsel ve işitsel iletişimin bir hak olarak anayasada düzenlenmiş olması onun kullanılması üzerindeki devlet tekelinin kaldırılmasını da gerektirmiştir.

Özgürlük rejimi konusundaki diğer bir argüman da "resmi makamların müdahalesi"nden masuniyeti şart koşan hükümdür. Böylece Anayasa söz konusu özgürlüğün kullanılmasında kamu gücii kullanan her hangi bir organın özgürlük kapsamındaki eylemlere karışmamasını emretmiştir. Bu nedenle devletin ya da diğer kamu tüzel kişilerinin bu alandaki faaliyetlere yapacakları "miidahale ${ }^{\text {th }}$ ler hukuksuz hale gelmiştir". Böylece fiilen oluşan özgürlük alanı anayasanın hükmü ile de desteklenmiş olmaktadır.

Fiili durumun idarenin işlevini radyo ve televizyon alanında sadece katılmacı konumuna getirmesi konuyu 26. maddedeki düzenleme ile çelişen 133. maddedeki sınırlandırmanın kaldırılması noktasına getirmiştir. Dolayısıyla hem Anayasadaki özgürlük rejiminin gereği hem de fiili durumun gereği olarak idarenin radyo-televizyon alanındaki işlevi (müdahale değil) 133. maddede yapılan değişiklikle yukarıda değginildiği uzzere iki boyutlu hale getirilmiştir. Bunlardan ilki olan kamu hizmeti sunumu bir kamu kurumu niteliğinde hizmet yerinden yönetim kuruluşlarının bir örneği olan TRT tarafından yerine getirilirken; ikincisi, kolluk faaliyeti, hizmet yerinden yönetim ilkesine göre kolluk faaliyetleri yapmakla görevlendirilmiş RTỦK tarafından yerine getirilmektedir. Anayasadaki bu değişiklikle ayrıca iletişim özgürlügüüün iki boyutu da kapsanır hale geImiştir. Çünkü iletişim özgürlüŭgu devletin müdahalesi olmadan yayın yapma özgürlüğii ve kamunun çok sesli bir ortamda nesnel ve hızlı haber ve düşüncelere ulaşma hakkını içermektedir(NALBANT: 113).

\section{RTÜK'ün İDARİ SİSTEMİMİZ İÇERİSINDEKİ YERİ}

Radyo ve televizyon alanında kamu gücü kullanan bir tüzel kişilik olarak RTÜK'ün nasıl ortaya çıktığını açıkladıktan sonra onun idari

\footnotetext{
${ }^{6}$ Burada müdahale ile kastedilen basın için olduğu gibì sansür yasağı değjl kamu gücü kullanan organların her türtü eylemi kontrol altında bulundurmalandır. Bu yöndeki yorumla bu alanda faaliyet gösteren kurumların düzenleme ve denetleme faaliyetleri değil engelleme faaliyetteri hukuk dışında gösterilmeye çalışılmaktadır.

${ }^{7}$ Burada Anayasa'nı bu normu kural olarak koyduğunu ancak istisnaların da hemen arkasından sıraladı ğını hatırlamakta fayda vardır. Ayrıca her düzenlemenin bir sınırlama olması mahiyetiyle oluşacak olan müdahalelerinde varlığını da unutmamak gerekir.
} 
sistemimiz içindeki yerini de belirlememiz gerekmektedir. Bu belirlemeyi kamu kurumu nitelememizden haraketle yapıp konuyu Türk idare sistemi çerçevesinde ele almak mümkündür. Ancak bu girişim RTÜK ya da ona benzer kuruluşlarının idari fonksiyondaki yerlerini açılamaya yetmez. Bu nedenle öncelikle bağımsız idari kurumların ayrımlanmasina değginmek gerekir.

\section{Bağımsız İdari Kurımların Sınıflandırılması}

Idari fonksiyon açısından bağımsız idari kurumların kapsayıcı bir sınıflandırmaya tabi tutulması zordur. Ancak Pliatzky'nin önerdi ği üçłü ayrımın genel bir kabul gördïğ sö sölenebilir. Buna göre bağımsız kurumlar: (i)idari (executive), kurumlar, (ii)danısman(advisory) kurumlar ve (iii)yargisal(tribunal) kurumlar olarak ayrılabilir(THOMPSON: 259). Bunlar arasında bizi ilgilendirenleri idari kurumlardır. Ídari kurumlar da kendi içinde fonksiyonları itibariyle ayrımlanmaktadırlar. Bunlar da (i)idari (managerial), (ii)düzenleyici ve denetleyici (regulatory), (iii)geliştírici (promotional) ve (iv)ticari (trading) idari kurumlar olarak sınıflandırılmaktadır $x^{x}$. Buradan da anlaşılacağı üzere bu ayrım içerisinde de bizim açımızdan önemli olan "regulatory" yani düzenleyici ve denetleyici olanlardir.

Bizi ilgilendiren kurumlardan düzenleyici ve denetleyici olanların kendi içinde bir sınıflandırmaya tabi tutulması mümkün dełildir. Çünkü bunlar faaliyet ifa ettikleri hukuk sisteminin karakterine uyum sağlamak için çeşitli fárklılkklar göstermelerine rağmen hemen hemen birbirinin aynıdılar. Değişen şey sistemin ihtiyaçları gereği genişleyen yetki alanlarıdır. Bu nedenle biz burada bu kurumlarn temel niteliklerinden kabul edilen (i) bağımsız ya da özerk olarak yapılandırılma ile (ii) diizenleme ve denetleme fonksiyonları(ULUSOY : 1999: 5) úzerinde bazı açıklamalar yapacağız.

\section{Bağımsız İdari Kurumları Karakteristikleri}

\section{Düzenleme ve Denetleme İşlevi}

Bağımsız idari kurumların ayırıcı ölçütü olarak düzenleme ve denetleme, "regulation" terimini karşılar şekilde kullanılmaktadır. "Regulation" işlevinin "belli (bir) faaliyet .... alan(nn) organize edilmesi (dïzenleme faalieti) ve bunun kontrol edilmesi(denetim faaliveti)" ni kapsadı̆̆ savunuImaktadır(ULUSOY : 1999: 6).

\footnotetext{
"Nakleden THOMPSON : 259. Ancak bu aynumın İngiliz hukuku jçin yapıldığın ve kabul gördišünü de hatırlatmak gerekir.
} 
"Regulation" işlevinin genel olarak düzenleme ve denetleme faaliyetlerini kapsadığın kabul ettikten sonra bunun radyo ve televizyon alanındaki tanımını da şöylece vermek mümkündür; "birilerini faaliyette bulunmaya mezun kılmak, onlarm yükümlülüklerini yerine getirip getirmediğini izlemek ve aksi durumda yaptırımlar uygulamak"(ROBILLAND: 4). Ancak diizenleyici ve denetleyici kurumlarm radyo ve televizyon alanındaki faaliyetlerinin bunlarla sınırlı olmadığı da savunulmaktadır. Buna göre söz konusu kurumların radyo ve televizyon alanındaki "regulation" işlevi sayllanlara ek olarak radyo ve televizyon yayın "alanmm organize ve koordine edilmesi", alana ilişkin normatif bir yapının oluşturulması ve bazen uyuşmazlıkların çözüme kavuşturulmasını da kapsamaktadır(ROBILLAND : 4).

\section{Özerklik}

Radyo ve televizyon alanında "regulation" işlevini iistlenen kurumların bağımsızlıkları ya da özerklikleri veya onun derecesi kurumun karar organımı oluşturan kurul üyelerinin seçimi ile onların faaliyetleri üzerinde klasik idare makamlarının yetkilerinin incelenmesi sonucunda açı̆̆a çıkacaktır. Bu araştırma (i) seçilen ïyelerin kural olarak idari makamlarca atanmaması veya kendilerine özgü metotlarla seçilmeleri, (ii) görevleri süresince önceki makamlarından ya da sahip oldukları makamdan alınamamaları, (iii) üzerlerinde idari denetimin geçerli olmaması, (iv) kararları izerinde yargı denetimi dışında bir denetimin geçerli olmaması unsurları dikkate alınarak yaptlmaktadir.

\section{RTÜK Özelinde Değerlendirme}

\section{Dïzenleme ve Denetleme İşlevi Açısından}

RTÜK, kuruluş kanununun 5. maddesi gereğince kamu tïzel kişiliğini haiz olarak teşkilatlandırılmıştır. Kanun bu kişiliğin özerk ve tarafsız olduğunu da hükme bağlamıştır(m. 5). RTÜK'ün özerkliğinden ne anlaşılmak gerektiģi şimdilik bir yana bırakılırsa onun düzenleme ve denetleme faaliyetlerine ilişkin görevlerinin belirlenmesi gerekecektir. Kurul, Kanunun 8. maddesinde sayılan geniş bir yetki demetiyle donatılmıştır. Bu yetkilerden; $b, c$ ve $d$ fikralarının ilk yarım cümlelerindeki yetkiler "faaliyete mezun kalmak"; h ve $\mathrm{k}$ fikralarmdaki yetkiler ile c ve d fıkralarının ikinci yarım cümlelerindeki yetkiler "yükümlïlüklerin yerine getirilmesini izlemek"; 1 fikrasmdaki yetki "yaptirım uygulamak"; b fıkrasının ikinci yarım cümlesindeki yetki "alanı organize ve koordine etmek"; f, g, p ve I fikralarındaki yetkiler ise "normatif yapı oluşturmak" ölçütlerine yönelik düzenlemelerdir. Bunları hepsi birlikte düşünüldäğünde, 
Kanunun de jure tanıdı̆̆ özerklik sıfatı da dikkate alındığında, RTÜK'üı bağımsız idari kurum olarak kabulü gerekmektedir.

\section{Özerklik Açısından}

\section{Olışumu Bakmmindan}

Kurulun olış̧umunda 3984 5. Kanunun ilk şeklinde klasik idari makamlara yetki verilmemiş ve kendine özgii bir metot benimsenmiştir. Ancak anılan Kanunun $4756 \mathrm{~s}$. Kanunla değiştirilmesinden sonma kurul üyelerinin seçimi usulü de ̧̧ş̧tirilmiş ve klasik idari makamlardan olan Bakanlar Kuruluna (BK) yetki verilmiştir. Eski usulde dokuz kişilik kurulda beş iiye iktidar parti ya da partilerince gösterilecek adaylar arasından: dört üye ise muhalefet partisi ya da partilerince gösterilecek adaylar arasından TBMM Genel Kurulunca seçilmekteydi". Yeni düzenlemeye göre ise dokuz. iyenin beşi TBMM Genel Kurulu Başkanlık Divanının oluşum formülüne göre TBMM Genel Kurulu tarafından seçilecek ${ }^{\text {la }}$ diğer dördü ise çeşitli

${ }^{4}$ Bu yöntem dokırinde sorunlu bulunmuş ve yeni yöntem öncrilerinde de bulunulmuştu.

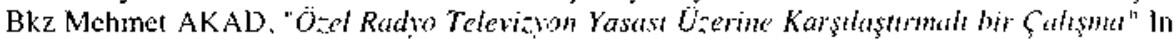
İlhan Akın'، Armağan. IÜHF Yaymları. İstanbui, 1999, s. 9-11.

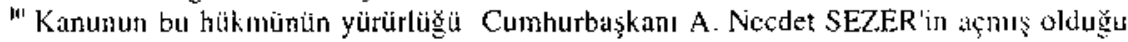
iptal davasinda (Dava dilekçesi için bk\%.

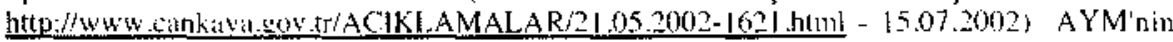
E. 2002/97. K. $2002 / 9$ (Y.D.) K.T. 12.6. 2002 tarihli karanyla durdurulmuştur. Karara

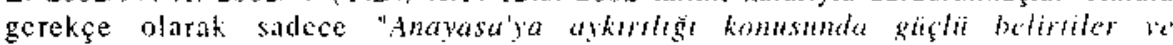

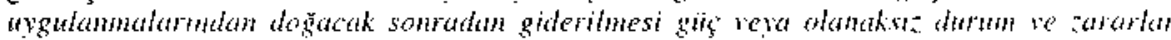
doğabileceği" ilidesi gösicrılmiştir. Anayasa Mahkemesinin bu kararının istem gerekçesind Cumburbaşkanı. TBMM'nin görev ve yetkilerinin Anayasanın 87, maddesinde taholidj olarak sayıldığını ve TBMM'nin bu sayıłanlat dışında yine 87. maddenin meminden harcketlo sadecc Anayasanın diḡer maddelerinde verilen görevleri yerine getirebilcecŏgini sirvummuştur. İstem gerckçesine görc TBMM kanunla kendine yeni görevler oluşturamayalcaktır. Bu ncdenle hükmijn iptali ve yürürlüğğünün de durdurulması istcnmiştir.

Bu noktada ilk olarak Anayasanın 87. maddesinin niteliğine değinmek gerckir. Anayasanın 87. maddesi gerekçesinde; "Anawasa'nun diğer maddelerinde ängorälon yetkileri kullanma ve görtleri yerine getime geklindeki hikinterin genel nitelikteki, gör'vleri

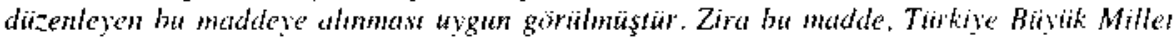
Meclisinin Anaysa'der gerek bu maddede gerek diğer maddelerinde däzenlemmis olan biärï görev ve yerkilcrini kapsayacak şekilde dïsïnülmüştï̀" denilerek madde 'toparlayct' olarak yazılmıstır. Ancak bu yazım iptal isteminin gerekçesinde kabul edildiği üzere 'fahdidi' olarak nitelendirilemez. Sadece anayasa tekniği açssından bütūn yetkilerin birarada görülebilmesini sağlamak amacıyla toparlayıcı olarak kabul edilmelidir.

İkinci olarak TBMM'ne kanunla Anayasada sayılmayan yetki verilmesi mesclesinc değinilmelidir. Doktrinde báza yazarların belirttiğ gibi 87. muddenin metninde baza görevler

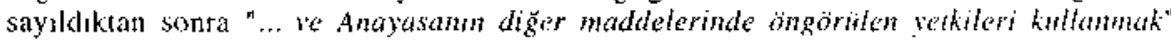
ibaresi ve gerekçe bat alınarak kanunla TBMM'ye yeti yetkiler tanmamayacagi kabul edilebilir. Aksi durumun Anayasanın 6.maddesine aykırılık oluşturduğ savumulabilmektedir (SABUNCU: 184). Ancak bizin de kabul ettiğimiz görüşe göre yasama yetkisinin genel olması onun mutlaka Anayasaya dayanmasım değil anayasaya aykırı olmamasıı tiade eder. 
Bu çerçevede yasama yetkisinin kullanılma aracı anlamında kanun, secundum legem değj] intra legem (GÖZLER'in ifadesiyle intra constitutionem (GÖZLER : 470))'dir. Yani Anayasaya dayanmak durumunda değildir. Anayasaya aykırı olmaması yeterlidir. (ÖZBUDUN: 192; GÜNDAY: 2002: 43). Dolayısıyla RTÜK'e ilişkin Anayasada açıkça bir düzenleme olmadtğından TBMM bir kanunla RTÜK'e üye seçme yetkisini yasama yetkisinin genellizi jlkesine dayanarak kendisine tantyabilir. Nitekim TEZiÇ"de "yasama organ Anayasaya uygun olmak koşulu ile her konuyu dïzenleme kapsamma alabilit" ifadesiyle yasama yetkişnin astiliğini açıklatken yasama organının uymak zorunda olduğu koşulun "Anayasaya dayanmak" değif "Anayasaya aykırı olmamak" olduğunu belirterek yukarıdaki görüşümüzü destekler nitelikte bir yaklaşım ortaya koymuştur (TEZZiÇ: 14).

Bu konuya ilişkin bir diğer argüman da şu şekilde geliştirilebilir; Türk hukuk düzeninde yürütmenin özerk bir a!aıı olmadığı konustında tartışma yoktur (CB Genel Sekreterliği Kararnameieri istisna tutulmak kaydıyla). Dolayısıyla "TBMM kanunla diazenleme yaparken belli konulardaki yerkileri mutlaka Yürümeye tamyacaktr, hunlar kendisi kullananız" denilmesi mümküin değildir. TBMM istediği yetkiyi Yürütmeye istediğini kendisine tanıyabilir. Dolayısıyla niteliği itibartyla şart işlem olan RTÜK'e üye atama yetkisinin Yürütme organına tanınacağına ilişkin bir çıkanıma varılması hukuk sistemimiz açısından bizce mümkün de gildir. Bu nedenle de $4756 \mathrm{~s}$. Kanunun iptal istemine konu hükmünün Anayasaya aykırı oldığunu savunmak mümkün değildir.

Burada son olarak iptal isteminin gerekçesinde dayanılan AYM kararına da değinmek gerekir. AYM. Sayıştay'a TBMM Komisyonları tarafından yapılan üye seçme işlemini düzenleyen kanuna karşı yapılan başvuruys incelerken 87. madde açısından yapı ı̆ı incelemede; "TBMM ile Sayıştay arasındaki (adına denetim yapma) ilişki(si) Sayıştay'm kuruluşunu, uyelerinin seçimini, denetiminin kapsantm ve böylece hukuksal yaptsm belirler.

TBMM adna denerim yapan anayasal bir organm Baskan ve üyelerinin seçimi Anayasa da gösterilmemiş ise de, bu seçinlerin TBMM Genel Kurulutca yapilması anayasal sistemin, diğer bir anlattmia TBMM ile Saytştay arastndaki ilişkinin doğal sontucudu)" (AYM Kararı. E. 1990/39 K. 1991/21, K.T. 11. 7. 1991, AMKD S. 27, C. 1. s. 449 )açıklamalarına yer vermiştir.

Bu ifadelerden AYM'nin 87. maddedeki sayımı tahdidi anlamaması için ilgiti kuruluş ile TBMM arasında özel bir iljşkinin varı̆̆ını aradığı açıktır. Ancak bu tavır bizce yasama yetkisinin genelliği ilkesi karşısında geçetli olamaz. Nitekim TBMM İnsan Haklan Komisyonunun Kurukmasına Dair 5.12 .1990 tarih ve 3686 s. Kanunla da TBMM Genel Kuruluna üye seçme görevi verilmiştir ki bu komisyon TBMM dışında inceleme ve araştırmalarda bulunmaya yetkili olması nedeniyle điğer komisyoniardan farklı bir komisyondur.

Bütủn bunlar birlikte düşünüldügünde AYM'nin anılan kararına paralel davranarak TBMM Genel Kuruluna yetki veren hükümleri iptal etmesi beklenebilir. Bunun bir işaretj olarak da ilgili hükümlerin yürürlüklerini durdurmuştır. Ancak bu yöndeki bir karar bizce yasama yetkisinin genelliği ilkesine ve dolayısıyla Anayasaya uygun bir yorum değildir.

AYM'nin $4756 \mathrm{~s}$. Kanında yürürlügünü durdurduğu maddeler arasında Kurulun oluşumunı düzenleyen maddenin TBMM Genel Kuruluna yetki tanıyan hükmü olmasına rağmen BK'na yetki veren hükmü yoktur. Dolayısıyla bu hükümler yürürslüktedir. Ancak Mahkeme önceki seçim kompozisyonundan yeni kanunla öngörülen kompozisyona geçişe ilişkin Geçici 4. maddenin yürürlügünti bütuinü jle durdurarak BK'nun sahip oldı̆gu yetkiyi ve henuz yürürlükte bulınan yetkilerin hangi şekilde kullanacağına ilişkin bì boşluk yaratınıştır.

İkinci olarak bugünkii hakuki durumda RTÜK ùyelerinin görev süresi dolduğunda (nitekim ìç ỉyenin görev süresi dolmuştır) BK'nun kendisine tanınan yetkiyi kullanabilip kullanamayacağını belirlemek gerekir. Dokuz üyenin dördü BK tarafından çeşitli kurułuşlarca önerilecek kişiler asasından seçilecektic. BK hangi üyelerin görev süresi dolduğunda atama 
kuruluşların gösterecekleri adaylå arasından BK tarafından atanacaktır. BK'nın yapacağı atamaların ikis:̈. YÖK Genel Kurula tarafundan belli nitelikleri haiz dört kişi arasından; biri, en çok sarı basın kartı sahibi iki Gazeteciler Cemiyeti ile Basm Konseyi tarafından ortaklaşa gösterilecek iki aday arasından ve son biri de MGK Genel Sekreterliğinin göstereceği iki kişi arasindan yapılacaktır. Hem TBMM kararının hem de BK kararnamesinin RG'de yayımlanacağı da kanunda hükme bağlanmıştır.

Kanunuu değişik şeklinin de tıpkı önceki hali gibi bir çok sorunu bünyesinde barındırdığı açıtır. Öncelikle TBMM Genel Kurulu önceden dokuz ìyeyi iktidar ve muhalefet partileri ayrımı çerçevesinde seçerken şimdi sadece beş üyeyi Başkanlık Divanının oluşum formülüne göre seçecektir. TBMM Başkanlık Divanı Anayasanın 94. maddesine göre "Meclisteki siyasi parti gruplarmn ïye sayss oraninda divana kathlmalarm sağlayacuk şekilde" kurulmaktadı. Öyleyse RTÜK'e seçilecek beş üye de Mecliste grubu olan siyasi partiler arasında milletvekili sayısma göre orantılı olarak dağıtrlacaktır. Bu metodun da önceki gibi birçok sorunu bünyesinde barındırdığı açıktır. TBMM Genel Kuruluna verilen bu yetki önceden olduğu gibi yeni düzenlemede de Sayıştay'a üye seçme gibi bir Parlamento Kararı ile kullanılacaktır. Nitekim bundan önce böyle olmuştur. Bilindiği izzere Genel Kurul işlemleri ya kanun olur ya da parlamento kararı. Bir kanun olmadığına göre işlem bir karardır. Peki bu kararın denetimini kim yapacaktır? İ̧lem parlamento tarafından yapıldığından organik olarak bir yasama işlemidir. Bu nedenle olsa olsa Anayasa yargısının denetimine tabidir. Ancak parlamento kararlarından hangilerinin Anayasa yargısına tabi olduğu Anayasada sayılmış ve RTÜK'e üye seçme işlemi bunlar arasında gösterilmemiştir. Karar bir içtüzük değişikliği olarak da nitelenemeyeceğinden Anayasa yargısı denetimi dışındadır. O halde işlemin niteliği itiburriyle bir çözüm bulmak gerekmektedir.

Genel Kurul'un işlemi bir kişiyi koşulları daha önceden kanunla belirlenmiş bir makama atama işlemi yani bir şart işlemdir. Dolayısıyla idari

yapabilecektir? Bu konuda açık hüküm olmamakla birlikte, Geçici 4. maddenin Geçici I. madde ile birlikte okunmasından, 4. maddeye göre seçilecek üyelerin Resmi Gazetede jlan ile birlikte önceki đüzenlemeye göre görev süresi dolmamış olsa da bütün üyelerin görev süresinın dolduğunu anlamak gerekmektedir. Bu maddenin jse yürürlüğï durdurułmuştur.

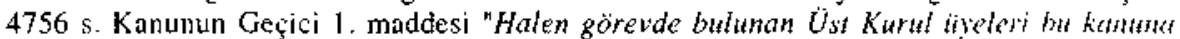
göre seçilecek veni Ust Kunt ïvelerinin seçim sonucumun ... Resmi Gäetede yatumlammast tarihlerine kador görevlerine devam ederler" hükmünü havidir. Dolayısılyla eski sç̧im kompozisyonundan yeni seçin kompozisyonuna intibakı düzenleyen Geçici hükümlerden Geçici 4. maddenin yürürlüğü durdurulduğu ama görevi biten Kurul üyclerinin yerierine gelecek kişilerin bclirlenmesine kadar göreve devam edeceklerine ilişkin Geçici 1. maddenin yürürlü đü durdurulmadı ğı için görev süresi biten mevcut üyelerin görevlerine devam ctmeleri gerekir. Dolatyısıyla BK kendisine tanınan yetkiyi sorun AYM tarafından çözzuliünceye kaçar kullanamayacaktır. 
yargının denetimine tabi olması gerekir. Çünkü yapılan iş niteliği itibarıyla, idari fonksiyona dahil bir işlemdir. Bu nedenlerle işlem parlamentonun idari bir işlemi sayılacak ve denetimi idari yargı mercilerince yapılacaktır. Ídari yargı mercilerinden Danıştay ilk derece mahkemesi olarak istisnai yetkili bir mahkeme oldugundan sadece kendi kanununda sayılan davalara bakabilecektir. Danıştay Kanununda bu yönde bir açıklık olmadığından açılacak davaya Ankara Idare Mahkemelerinin bakması gerekecektir.

Yukarıda RTÜK'e üye seçme işlemine denk olarak nitelediğimiz Sayıştay'a üye seçme işlemine karşı açılan bir davada Ankara İdare Mahkemesi, işlemin denetlenemeyeceğinden bahisle ret kararı vermiştir. Bunun üzerine temyiz yoluyla Danıştay nezdinde yapılan başvuruda yüksek mahkeme işlemi denetlemekten kaçınmıştır. Danıştay kararında;

"... iptal davalarinda idari yargt denetimi yaptlabilmesi için iki unsurun bir arada bulunması gerektiği ortaya çıkmaktadır. Bu unsurlar, idari makam ve bu makamca tesis edilmis olan kesin ve yürïtülmesi zorunlu nitelikte bir islemin varlığıdır. Idari makam ve mercilerin, idari görevleriyle ilgili olarak tesis ettikleri tek tarafli doğrudan uygulanabilir nitelikteki işlemler idari işlem olarak tantmlanmaktadır. Bir işlemin 'idari işlem' olarak tanımlanabilmesi için o işlentin idari bir makam tarafindan tesis edilmiş olmast genellikle kabul edilmektedir.

Kuvvetler aynllğı ilkesini benimsemiş olan Anayasamızda TBMM'nin görev ve yetkileri Yasama bölimünde düzenlenmiştir. Bu haliyle TBMM Genel Kurulunun ... Anayasa sistemimiz içinde 'idari makam' olarak düşünülmesi hiçbir şekilde mümkün degildir....

Açıklanan duruma göre idari makam olarak kabul edilemeyeceği tartışmastz olan yasama organınin Sayıştay'a üye seçilmesiyle ilgili olarak ... 12.11.1985 tarihinde TBMM Genel Kurulunca onaylanmts olan tasarrufun idari yargı denetimine tabi tutulması olanak dışıdı"( D. 5. Dai. , E. $1987 / 2379$, K. $1987 / 1785$, K.T. 25.3.1987, DKD, S. 70-71, s. 273-74).

Açıkça görülmektedir ki Danıştay organik ölçüt çerçevesinde bir değerlendirme yapmış ve Anayasa Mahkemesinin denetlemediği bir tasarrufu denetlemekten kaçınmıştır. Biz Danıştay'ın görüşüne katılmıyor, işlemin maddi ölçüt çerçevesinde idari olarak nitelendirilmesi gerektiğini düşünüyoruz. Nitekim TBMM Genel Kurul'unun Sayıştay'a üye seçerken yaptığı işlem ile RTUK'e üye seçerken yaptığı işlemin de aynı karakterde olduğundan bahisle idari yargı denetimine konu olması gerektigini benimsiyoruz. Çünkü Anayasanın amir hükmü gereği idarenin her türlü işleminin yargı denetimine konu olduğunu ve hükümde idari fonksiyona 
dahil her türlü işlemin kastedildiğini dủşünüyoruz. Ayrıca bu işlemin istisna olarak sayılmadığına da dikkat çekmek istiyoruz. Dolayısıyla söz konusu işlem, idare organlarınca yapılmasa da idari fonksiyona dahil bir işlem olmak niteliğiyle idari yargı denetimine tabi tutulacak ve Danıştay'ı görevleri arasında sayılmadığından genel yetkili idare mahkemelerinin (Ankara İdare Mahkemeleri) denetimine tabi tutulacaktır(Ayrıntılı bilgi için YILMAZ: 157-8),

3984 s. Kanunda 4756 s. Kanunla yapılan değişiklikle RTÜK ïyelerinin dördünün çeşitli kurumların önerdiği kişiler arasından Bakanlar Kurulunca atanacağı hükme bağlanmıştır. Böylece diğer bağımsız idari kurumlarda olduğu gibi kurumların karar organları olan kurulların oluşumunda siyasal etkiye açık kapı bırakılmış olmaktadır. Bu husus kişilerin yeniden atanabilecekleri gerçeģi ile birlikte düşünüldüğünde kurumların bağımsızlıklarına yönelik bir zayıflatıcı öğe olarak degerfendirilebilecç̆i(GÜNDAY : 2002: 495) gibi halk karşısnda kurulların faaliyette bulunduğu alanın siyasal sorumluluğunu üstlenen yürütme organının asgari de olsa kurulları etkileme olanağı olarak değertendirilip olumlu da bulunabilir.

Bakanlar Kurulunun yapacă̆ı bu atama işlemlerinin ise şatrt işlem niteliğinde idari işlem olduğu ve Bakanlar Kurulu işlemi olmak itibarıyla Danıştay'ın yargı alanına girdiğinde şüphe olmamak gerekir.

\section{Uyelerin Görev Sïresi Bakmundan}

Kurumun karar organını oluşturan kurul üyelerinin görevleri süresince önceden ifa ettikleri görevlerinden ya da şimdiki görevlerinden almamamaları yönündeki ilke Kanunun 10. maddesinde "Üst kw ïyeleri seçildikleri görev siiresince Kurul'daki görevlerinden we seçilerek goldikleri görevlerinden alıamazlar" şeklinde hükme bağlanmıştır. 3984 s. Kanunun $4756 \mathrm{~s}$. Kanunla değişik 9. maddesi ise ùyelikle bağdaşmayan durumları belirlemiş ve bu hallerin mevcudiyeti halinde iyelerin "görevlerinden ફ̧ekilmiş say/(trlar)"masını hükme bağlamıştır. Çekilmiş sayılmaya re'sen veya müracaat üzerine üst kurulun kendisi karar verecektir. Bu konuda bir ihtilaf çrkması halinde ise karar verme yetkisi ilgili yargı organında olacaktır. Bu da doğaldır ki Ankara İdare Mahkemeleri olacaktır.

\section{Kurul Kararlart Uzerindeki Yetkiler Bakımından}

Bağımsızlı̆̆ın ya da özerkliğin unsurları arasında saydı̆̆ımız son husus ise Kurul'un kararları üzerinde idari makamlara bir yetki tanınmamış olması idi. Nitekim ileride görüleceği iizere kamu hukukunda yetkisizlik asıl, yetki 
istisna olduğundan hiçbir (idari) makam kendisine verilmemiş bir yetkiyi kullanamaz. Bu nedenle Kurul kararları üzerinde hiçbir makama yetki tanınmadığından bu unsur da gerçekleşmiş kabul edilmelidir.

\section{Mali Kaynaklar Bakımindan}

Bağımsızlık ya da özerklik konusuna son vermeden önce kurumun mali açıdan gösterdiği özelliğe de değinmek gerekmektedir. Çünkü mali açıdan idareye bağımlı olan bir yapı diğer unsurları ne kadar sağlarsa sağlasın o yetkiler içi boş kalmaya mahkumdur. Ancak RTÜK açısından böyle bir tehlike de söz konusu deģildir. Çünküi RTÜK'ün gelir kaynağı olarak, radyo televizyon alanında faaliyette bulunan aktörlerin reklam gelirlerinin brüt yüzde beşi,özel kuruluşlara yaptlacak tv kanal ve radyo frekansı yıllık tahsis bedelleri ve özel radyo tev kuruluşlarına kesilecek idari para cezalanı olarak gösterilmiştir. Ayrıca gerektiğinde TBMM bütçesinden ödenek aktarılması da karara bağlanmıştır(m. 12). Böylece RTUK mali açıdan hiçbir idari makamla muhatap olmayacak şekilde düzenlenmiştir. Bu düzenlemenin RTÜK için yukarıda anılan tehlikeyi kolaylıkla bertaraf ettiği de açıkır.

Bu açıklamalar ışığında RTUK'ïn bağımsız bir idari kurum olarak kabul edilmesi gereği tekrar açı̆̆a çıkmışırı. Peki kurum Türk idare sistemi içerisinde nerede yer alır? Bunu belirleyebilmek için RTÜK'ün anayasal organlarla olan ilişkilerinin açıklığa kavuşturulması gerekmektedir.

\section{Anayasal Konum}

\section{Genel Olarak}

RTÜK Anayasamızda açıķ̧a düzenlenmemiştir. Ancak 133. maddedeki ifadenin bu alanda kurulacak yapının anayasal dayanağı olduğu savunulmaktadır(DURAN: 1999: 9). Bizce Anayasanın adı geçen hükmü kurulacak yapının değil, kurulacak radyo televizyon istasyonları ile onların faaliyetlerinin anayasal dayanağı olarak yorumlanabilir. Zaten bütün kamu tüzel kişilerinin Anayasadan özel atıf alması da gerekmemektedir. Çünküi hepsi, aşağıda göreceł̆imiz, idarenin örgütlenme ilkelerinden genel bir atıf almışlardır. Ayrıca Anayasa'da kendisine özel atıf yapılması bir kurum ile diğeri arasında bir hiyerarşiye de neden olarak gösterilememektedir(GÖZÜBÜYÜK - TAN: 291). Bu nedenle bizce sorunu ilgili Kanun ve genel hükümler çerçevesinde çözmek gerekir. 3984 s. Kanunun 5. maddesinde belirlenen kamu tüzel kişiliģinin bir kamu kưumu olmak şeklinde anlaşılması gerektiğine yukarıda değinmiştik. Bu kamu tïzel kişisinin ifa ettiği fonksiyonun idari olduğunda da bir şüphe yoktur. Özetle, RTÜK idari fonksiyon ifa eden bir kamu kurumu olarak irdelenecektir. 


\section{Idarenin Tabi Olduğu Ilkeler Bakmmindan}

Anayasamız idarenin örgütlenme ilkesi olarak merkezden yönetim ve yerinden yönetim olmak üzere sadece iki ilke öngörmüştür(m. 123), Dolayısıyla kamu tüzel kişilerinin örgütlenmesi sadece bu ilkeler çerçevesinde gerçekleşebilecektir. Bu doğrultuda merkezden yönetim ilkesi çerçevesinde devlet idaresi; yer yönünden yerinden yönetim ilkesi sonucunda mahalli idareler: hizmet yönünden yerinden yönetim ilkesi çerçevesinde de kamu kurumları örgütlenmişlerdir. Bu nedenle Tüirkiye'de ancak devlet idaresi, mahalli idareler ve hizmetsel kuruluşlar olmak üzere üç̧ tip teşkilat olabileceği ortaya çıkmaktadır.

Burada RTÜK'ün bu kategoriler içerisinde nerede konumlandırılacağı izzerinde durmak gerekmektedir. Hizmetsel kuruluşlar incelendiğinde bunların bir hizmet teşkilatının ayni ve şahsi vasıtalarmın kamı tüzel kişiliğine sahip kılınması ile oluştuğu gözlenir. Dolayısıyla bu kuruluşlar esasen kamu hizmeti sunumuyla görevlidirler. Ancak RTÜK'ün böyle bir işlevi yoktur. RTÜK kendi özel kanunu ile kamu tïzel kişiliğini haiz şekilde kurulan ve belli bir hizmet alanının düzenlenmesi ve denetlenmesi ile görevłendirilen bir kamu kurumudur. Bu nedenle daha öncede ifade edildiği üzere bir çeşit özel kolluk faaliyeti yerine getirmektedir.

Sonuç olarak RTÜK anayasal planda hizmet yerinden yönetim kuruluşlar içinde yer alacak ancak kamu hizmeti sunumuyla görevli olanlardan farkı bir kategoride sinıflandırılacaktır.

Bu noktada RTUKK'ün hizmet sunumuyla görevli kamu kurumları ile ayrılabildiği bir diğer nokta üzerinde daha durulmalıdır. Klasik olarak nitelendirilebilecek kamu hizmeti sunucusu kamu kurumları devlet idaresinden ayrı tüzel kişiliğe sahip olarak düzenlenmelerine rağmen idarenin bütünlïğü ilkesi geteği idari vesayet denetimine tabi kılınmışlardır.

İdarenin bütünlüğï ilkesi, oluşum yönünden ve işleyiş yönünden bütuinlük olmak üzere iki boyutta ele alınır. İdarenin oluşum(kurutuş) yönünden bütünlüğgi kural olarak, idari fonksiyon ifa eden her yapının kişiliğnini Anayasadan, kanundan ya da kanunun açıç̧a verdiği yetkiye dayanan idari işlemden alması anlatımıyla tanımlanırken; idarenin işleyiş yönünden bütünlüğui. yine idari fonksiyon ifa eden her yapmın hiyerarşi veya idari vesayet denetimi ile merkezi idareye bağlanması anlatımıla tanımlanır(GÜNDAY: 2002: 74-5). Bağımsız idari kurumların, bu arada RTÜK'ün hiyerarşi denetimine tabi olmadığını önceden belirtmiştik. Dolayısıyla elimizde sadece idari vesayet denetimi kalmaktadır. 
3984 s. Kanun incelendiǧnde RTÜK üzerinde idari vesayet yetkisine sahip bir devlet idaresi organına yer verilmediği görülecektir. $O$ halde RTÜK'ün, kamu kurumları içerisinde yeni tanımlanacak ayrı bir kategori oluşturduğu mu (GÖZÜBÜYÜK-TAN : 289-90) yoksa klasik idari yapılanma açısından tanımlanan idari vesayetin çağın ihtiyaçları doğrultusunda oluşan bağımsız idari kurumlar düşünülerek yeniden tanımlanması gerektiği mi savunulacaktır?(ULUSOY : 2000: 49; ULUSOY, 1999: 14).

Devlet idaresinin mahalli idareler üzerindeki idari vesayet yetkisi Anayasanın 127. maddesinin 5. fikrasında;

Merkezi idare, mahalli idareler üzerinde mahalli hizmetlerin idarenin bütünlı̈̋̆gü ilkesine uygun şekilde yürütülmesi, kamu görevlerinde birliğin sağlanması, toplum yararının korunması ve mahalli ihtiyaçların gereği gibi karşılanması amacıyla, kanunda belirtilen esas ve usuller çerçevesinde idari vesayet yetkisine sahiptir

şeklinde düzenlenmiştir. Burada bizim için önemli olan idari vesayet yetkisinin "kanunda belirtilen esas ve usuller çerçevesinde" kullanılacağ1 ibaresidir. Dolayısıyla kullanılacak vesayet yetkisinin kanunla belirlenmesi gerekmektedir. O halde yapılacak iki şey kalır: (i) idari vesayet yetkisi olarak bilinen yetkilerin ilgili kanunda aranması ve/veya (ii) ilgili kanunda devlet idaresinin organlarina tanman ancak bilinen idari vesayet yetkilerinden olmayan yetkilerin de idari vesayet yetkisi olarak kabul edilmesi.

3984 s. Kanunun incelenmesi sonucunda görülecektir ki ne bilinen idari vesayet yetkilerine ilişkin bir düzenleme vardır ne de merkezi idareye, idari vesayet olarak nitelendirilmesi mümkün bir yetki tanınmıştır. $O$ halde ne olacaktır? RTÜK idarenin bütünlügü ilkesinden masun mu kabul edilecektir? Bizce hayır. Çünkii bu durum Anayasanın ruhuna aykırı olur. Burada eksik düzenlemeden kaynaklanan bir yasa boşluğunun kabulü bizce en dogru yoldur. Çünkü Anayasanın öngördüğü bir ilke (yerinden yönetim) çerçevesinde örgütlenen(ULUSOY : 1999: 12), Anayasanın öngördüğ̈ü kamu tüzel kişiliği sıfatlarından kamu kurumları içerisinde mütalaa edilen ve idari fonksiyon ifa ettiğinden şüphe olmayan bir kurum üzerinde, bu sonuçların bir gereği olan idari vesayet yetkileri düzenlenmemiştir. Dolayısıyla RTÚK kuruluş itibarıyla idarenin bütünlüğü ilkesine tabi olmasına rağmen işleyişi itibariyle bu ilkeye tabi kabul edilemeyecektir. Burada boşluk oldugunu kabul en doğru çözümdür. Ayrıca devlet tüzel kişiliği organlarına hiçbir yetkinin tanınmadığı bir düzenlemeyi idari vesayet olarak kabul etmek bizce olanaklı değildir. Şöyle ki; bir görüşe göre bu tip 
bir düzenleme karşısında ilgili kanunda "ilişkili" olarak öngörülen bakanlıkların kưumun işlemleri üzerinde hukuksallık denetimini başlatma noktasında idari yargı kriteri olan "menfaatin ihlal edilmesi" ölçütünden masun kılınması idari vesayetin yeni tanımı olarak kabul edilebilir" (ULUSOY: 2000: 51 ; GÜNDAY: 2002: 498-9) ${ }^{12}$.

Bütün bu nedenlerle bağımsız idari kurumların bu arada RTÜK'ün kamu kurumları içerisinde yeni bir kategori oluşturması önerisi(GÖZÜBÜYÜK- TAN: 289-90) kabul edilmelidir. Ancak bu ayrım idari vesayet yetkilerinin yokluğuna dayandırılmamalıdır. Çünkü bizce burada bir kanun boşluğu olup halk karşısında bağımsız idari kurumların faaliyet alanlarının da siyasal sorumluluğunu üstlenen BK'nun bu yetkilere sahip kilınmasi gerekmektedir. Bizce farklı sinıflandırma klasik kamu kurumlarının tersine kamu hizmeti degil de kolluk faaliyeti yapıyor olmalarına dayandırılmalıdır. Daha önce ifade edildiği üzere bu kurumların "regulation" şeklinde isimlendirilen düzenleme ve denetleme yetkileti bir hizmet alanının kendine özgü düzeninin kamu gücü kullanan bir organ tarafından sağlanması şeklindeki özel kolluk faaliyetidir. Ayrıca bu noktaya denetleme faaliyeti içinde kurumlarm sahip oldukları yarı yargısal yetkilere de dikkat çekmek gerekmektedir. İşte bu noktayı da değişen idari işlevin en önemli göstergelerinden biri olarak kabul etmek mümkün olabilir.

Kamu hukukunda yetkisiz sorumluluk olamayacağından RTÜK ile ilişkili olduğu 3984 s. Kanunun 14. maddesinde belirlenen Başbakianlık ya da onun görevlendireceği Devlet Bakanlığı kurumun faaliyetlerinden ya da faaliyetsizliğginden buguinkï hukuki düzenlemede her hangi bir sorumluluk taşımayacaktır.

RTUK'in aşağıda belirlenecek görevleri nedeniyle yapacağ faaliyetlerinin denetimi konusunda 3984 s. Kanun 39. maddesinde. "Üst kurul aleyhine açllacak idari davalarda Ankara Mahkemeleri yetkilidir" hükmünü getirmiştir. Dolayısıyla RTÜK idari fonksiyonu ifa sirasında yapacağı kişisel ya da değil her türlii faaliyeti ile yargı organları karşısında kişilere ve topluma karşı sorumlu olacaktır.

"Ancak bu görüşiün iki nedenle tartışmaya açık olduğunu da belirlemeliyiz. Bunların; birincisi. çünkü ilişkili bakanlıklar zaten nitelikleri gereği her durumda "menfaar ihlali" kriterini săglayacaktur. Bu nedene dayalı olarak söz konusu ilişki kurulabilmektedir. Ikincisi. anılan kabul iliş̧iłi bakanlığa işlem üzerinde hiçbir doğrudan yetki tanımamakta araya ilişkili bakanlıkla hiçbir şekilde idari ilişkisi olmayan bağımsız yargı organlarını koymaktakır.

${ }^{12}$ GUNDAY bu yetkiyi açıkça idari vesayet olarak adlandırmamakta ancak bu yola idarenin bütüntüğü ilkesinin gerçełleştirilebileceğini ifade jle yakın bir yorum henimsemiş görinmektedir. 


\section{RTÜK'ün DENETIMI}

Burada maksadımız RTÜK üzerindeki denetim mekanizmaları hakkında bazı açıklamalar da bulunmaktadır. Bu anlamda RTÜK'ün işlemleri üzerinde kanundan kaynaklanan yargı denetimi dışında RTÜK üzerinde yapılması olası siyasal ve mali denetime de değineceğiz.

\section{Siyasal Denetim}

RTÜK'ün idari fonksiyona dahil faaliyetlerde bulunduguna ve kuruluş itibariyle de idare bütününe dahil olđuğuna daha önce değinmiştik. Dolayısiyla bu kurum üzerindeki siyasal denetimin de idarenin siyasal denetimi sistematiği içerisinde yapılması savunulabilir. Bilindiği ïzere idarenin siyasal denetimi hem siyasal hem de idari kimlikleri bulunması nedeniyle bakan'ların parlamento tarafından sorumluluklarmm ileri sürülmesi şeklinde cereyan etmektedir. Çünkü bakanlar en üst amiri oldukları hizmet teşkilatı üzerinde hiyerarşi; o hizmete bağlı ya da onunla ilgili tiizel kişiler üzerinde de idari vesayet yetkisi ile donatılmışlardır. Kamu hukukunda sorumlulugun ancak yetki sonucu olduğu da aşikardır. Bu bağlamda bu yöndeki siyasal sorumluluk kabul edilmektedir.

RTÜK ile ilişkili olduğu Kanunun 14. maddesinde bildirilen Başbakanlığın ya da onun görevlendireceği Devlet Bakanlığının kurum üzerinde hiyerarşi veya idari vesayet yetkisine sahip olmadığına değinmiştik. Öyleyse bunlar nasıl sorumlu olacaktırlar? Bizce RTÜK'ün eylem ve işlemleri üzerinde bu nitelikte bir sorumluluk kurulması bugünkü hukuksal yapıda pek mümkün değildir. Ancak 3984 s. Kanunda 4756 s. Kanunla yapılan değişiklikle Kurumun en üst karar organı olan kurul üyelerinin dördünün $\mathrm{BK}$ tarafından seçileceği hükme bağlanmıştır. Fakat kurul üyelerinin görevlerini yerine getirmekte kusurlu olmaları durumunda organlık sıfatlarına ilişkin BK'nun bir yetkisi olmadığından BK'nun veya Başbakanlığın bu yönde bir sorumluluğu olduğuna hükmetmek doğru olmayacaktır.

RTÜK üyelerinin siyasi sorumluluğu yolu mümkün müdür? RTÜK üyelerinin siyasal bir organ olan Parlamento Genel Kurulu tarafından seçildikleri, bu nedenle siyasal sorumluluklarına bu noktada başvurulabileceği akla gelebilir. Ancak seçildikleri görev itibariyle siyasj nitelikleri olmayan ve hiçbir şekilde siyasal bir işlev de yerine getirmeyen üyelerin siyasal sorumluluğu yoluna gidilmesi mümkün olmamalıdır. Buna ek olarak görevin ifası sırasında Parlamento Genel Kuruluna her hangi bir yetki de tanınmadığından denetim söz konusu olamaz. 
TBMM'nin RTÜK üzerindeki siyasal denetimi bizce ancak onun bütçesi ile ilgili bir kalem sayesinde mümkündür. Bu da RTÜK'ün bütçe kalemlerinden biri olan TBMM bütçesi transfer tertibinden aktarlacak olan miktardır. Bunun dışında bir siyasal denetim yolu bulmak bize mümkün görünmemektedir.

\section{Mali Denetim}

RTUK'ün gelir kaynaklarının Kanunun 12. maddesi uyarınca, alanın aktörlerinin reklam gelirlerinin brüt yüzde beşi, özel kanallara yapılacak televizyon kanal ve radyo frekansı yıllık tahsisi bedelleri, özel radyo televizyon kuruluşlarına kesilecek idari para cezalarından ve TBMM bütçesinin transfer tertibinde yer alan ödenekten oluştuğuna değinmiştik. Bu gelir kaynakları üzerinde hiyerarşi ya da idari vesayet denetimi öngörülmediğinden devlet idaresine dahil birimlerin bu yönde bir mali denetim yetkileri yoktur. Ancak $3984 \mathrm{~s}$. Kanunun 12. maddesinin son fikrasi. "Üst kurulum bütçesi ... Plan Bütçe Komisyonunda incelenir ve Türkiye Büyük Millet Meclisi Genel Kurulunda görüşülerek karara bağlanir" hükmünú havidir. Dolayısıyla RTÜK'ün bütçesini inceleme ve gerektiğinde reddetme yetkisi TBMM'ye verilmiştir. Kanunun tanıdığı bu yetki doğaldır ki bir inceleme sonucunda kullanılacaktır. Sorun bu incelemenin ne şekilde yapılacağı noktasında düğümlenmekteydi. 4743 s. Kanundan (RG 31.01.2002 tarih 24657s. Mükerrer) önce bu konuda özel hüküm bulunmadığından 3984 s. Kanunun tanıdığı bu yetkinin Anayasa'da TBMM adına "... katma büţeli dairelerin gelir ve giderleri ile mallarm" denetlemekle görevli Sayışay tarafından hazırlanacak rapor üzerine kullanılacå̆ını söyleyebiliyorduk. Ancak 4743 s. Kanunun 7 . maddesi "... özel kanunlarla kurulmuş kanu tüzel kişiliğini ve idari ve mali özerkliği hais kurul, ust kurul ve bunlara bağlı kurumlarm yillk hesapları Babakanlik tarafindan belirlenen Başbakanlik müfettişi, Başbakanlik Yüksek Denetleme Kurulu denetçisi ve Maliye miifettişinden oluşan bir komisyon tarafundan

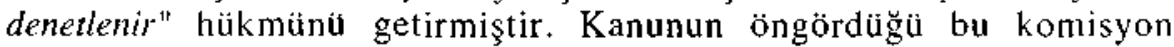
hazırladığı yıllık raporu Mayıs ayı sonuna kadar Başbakanlığa sunar ve ayrıca yılda bir kez de TBMM Plan ve Bütçe Komisyonuna bilgi verir. İşte TBMM $3984 \mathrm{~s}$. Kanunun 12. maddesinde kendisine tanına yetkiyi bu bilgilendirme üzerine Plan ve Bütçe Komisyonunun hazırlayacağı rapor üzerine kullanabilecektir.

Ayrıca 4743 s. Kanunun 7. maddesi kurul, üst kurul ve bunlara bağlı kurumlarm $6245 \mathrm{~s}$. Harcırah Kanunu, $1050 \mathrm{~s}$. Muhasebei Umumiye Kanunu ve 823 s. Sayıştay Kanununa tabi olmadıklarını da açıkça hükme bağlamıştır. Dolayısıyla anılan yetki Sayıştay'ın inceleme raporu sonucunda kullanilacaktır. 


\section{İdari Denetim}

RTÜK üzerinde yapılması olası idari denetimi ikiye ayırmak mümkündür. Bunların ilkj idarenin bütünlügüi ilkesinden kaynaklanan hiyerarşi ve idari vesayet denetimleri olup ikincisi Devlet Denetleme Kurulu( DDK) ve Başbakanlık Yüksek Denetleme Kurulu (YDK)tarafından yapilabilecek denetimdir.

Yukarıda RTÜK için hiyerarşi ve idari vesayet denetiminin mümkün olmadığnı görmüştük. Kısaca hatırlamak gerekirse hiyerarşi RTÜK'ün devlet tüzel kişiliği dışında bir kamu tüzel kişiliłg olması nedeniyle; idari vesayet ise kanunda açıkça öngörülmesi gerektiği halde böyle bir düzenleme olmadığı için mümkün değildir.

Devlet denetleme kurulunun yapacağı denetlemenin esası Anayasanın 108. maddesinde;

"idarenin hukuka uygunluğunun, düzenli ve verimli şekilde yürütülmesinin ve geliştirilmesinin sağlanmast amactyla, Cumhurbaşkanına bağlt olarak kurulan devlet denetleme kurulu, Cumhurbaşkanınin isteği üzerine, tüm kamu kurum ve kuruluşlarında, ... , her türlü inceleme, araştırma ve denetlemeleri yapar".

şeklinde ifade edilmiştir. RTÜK, Türk silahlı kuvvetleri organı ve yargı organı olmadığıdan bu denetimin kapsamında olacaktır. DDK'nın çalışması için Cumhurbaşkanınca açıkça görevlendirilmesi gerekir. Kurul inceleme ve denetleme sonucunu bir raporla Cumhurbaşkanına bildirir. Cumhurbaşkanı raporu onaylarsa gereği yapılmak üzere Başbakanlığa ve oradan da yetkili mercilere gönderilir. Sonuçtan Başbakanlık aracilı̆̆ıyla Cumhurbaşkanlığına bilgi verilir (Ayrıntı için GÖZÜBƯYÜ- TAN: 737 40).

Bu usûl dikkatle incelendiğinde ne Cummurbaşkanlı̆̆ı makamının ne de Başbakanlık makamının doğrudan işlem yapmadığı görülmektedir. Ayrıca zaten Başbakanlığın rapora dayalı olarak RTŬK iizerinde işlem yapması mümkün değildir. Çünkü ne hiyerarşi ne de idari vesayet yetkilerine sahiptir.

Diğer denetim yolu ise Başbakanlı YDK eliyle işletilebilecektir(Ayrıntı için GÖZUBUYYUK- TAN: 740-1). Nitekim bu denetime 3984 s. Kanunun 4756 s. Kanunla (RG 21.5.2002 S. 24761) değişik 9. maddesinde açıkça yer verilmiştir. Başbakanlık YDK da yapacağı denetim sonucunda icrai yetkilere sahip olmayan bir kuruluştur. Denetim sonucu Başbakanlığa sunulacak ve Başbakanlık yukarıda da anılan 
yetkisizlik nedeniyle deyim yerindeyse eli kolu bağlı kalacaktır: Ancak bu raporların TBMM denetimine asıl olduklarını anmakta da fayda vardır.

Bütün bunlar birlikte dikkate alındığında idarenin şeffaflığı ilkesi de hayata geçirilir ve hazırlanan raporlar kamuoyunun bilgisine sunulursa RTÜK'ün hukuka uygunluğu açısından etkili olacağını düşünüyoruz.

\section{Yargisal Denetim}

Burada RTÜK'ün eylem ve işlemleri üzerinde Kanunda öngörülmüßş bulunan yarğı denetimi hakkında bazı açıklamalar da bulunmak istiyoruz.

3984 s. Kanunun 39. maddesi, "Üst kurul aleyhine açlacak idari davalarda Ankara Mahkemeleri yetkilidir" hükmünü getirmiştir. Dolayısıyla RTƯK'ün işlemlerine karşı açılacak davalar idari yargıda ve Ankara Mahkemelerinde görülecektir. Bu sonuç aslında, daha önce de ele aldığımız gibi, idarenin her türlü eylem ve işlemini yargı denetimine tabi kılan Anayasa hükmünün de bir gereğidir. Çünkü RTÜK'ün yaptığı her türlü eylem ve işlem idari fonksiyona dahil olmakla idarenin eylem ve işlemlerinden sayılacak ve Anayasa'da sayılan yargı kısıntılarından kabul edilemeyeceğinden yargı denetimine tabi olacaktır. Ayrıca düzenleyici işlemlerin ifade hürriyeti yanında görsel ve işitsel iletişim hürriyeti ile direkt bağlantısı düşünüldüğünde, söz konusu düzenleyici işlemlerin, ve özellikle ceza ihtiva edenlerinin, yargı denetimine tabi tutulmaları büyük önem arz. etmektedir.

3984 s. Kanunun 39. maddesindeki "Ust kurul aleyhine açlacak idari davalarda Ankara Mahkemeleri yetkilidir" hükmü RTÜK'ün yaptığı düzenleyici işlemler bakımından da geçerlidir. RTÜK'ün diizenleyici işlemleri de tıpkı bireysel olanlar gibi Ankara Mahkemelerinin yetkisi içerisinde kabul edilmek gerekir. Çiinkü 3984 s. Kanun Danıştay Kanununa göre özel kanun niteliğindedir. Düzenleyici işlemlerin yurt çapında uygulanacak olması onlar aleyhine açılacak davaların Danıştay da görülmeleri sonucunu doğurmayacaktır.

\section{RTÜK'ÜN GÖREV ve YETKILERİ}

\section{Genel Olarak}

RTÜK'ün görev ve yetkileri $3984 \mathrm{~s}$. Kanunun 8. maddesinde 16 bentten müteşekkil olarak sayılmıştır. Biz bu çalışmada sayılan bütün yetkiler 
üzerinde ayrıntılı bir inceleme yolunu tutmayacak bir sınıflandırmaya gideceğiz.

RTÜK'ün yetkileri daha önce de ifade edildiği üzere beş toparlayıcı başlık altında ele alınabilir. Kanunda sayılan yetkileri bu başlıklarla birlikte hatırlayacak olursak; $b, c$ ve d fıkralarının ilk yarım cümlelerindeki yayın hizmetini yapacak işletmelerin kurulmasma ve bunların işletilmesine izin verme yetkileri "faaliyete mezun kılma"; $\mathrm{h}$ ve $\mathrm{k}$ fikraları ile c ve $\mathrm{d}$ fıkralarının ikinci yarım cümlelerindeki denetim yetkileri "yükiumliulïklerin yerine getirilmesini izlemek"; 1 flkrasındaki yetki "yapterm uygulamak"; b fıkrasının ikinci yarım cümlesindeki kanal ve frekans tahsisi yetkisi "alant organize ve koordine etmek" ", f, g, $1, \mathrm{p}$ ve l fikralarındaki düzenleme yetkileri ise "normatif yap oluşturmak" şeklinde nitelendirilmelidir.

\section{Dïzenleme İşlevine İlişkin Sorunlar}

RTÜK'ün yapacağı düzenlemeler ifade hürriyeti ile doğrudan ilgili olacaktır. Bu nedenle sinırlayıcı karakter arzeden düzenlemelerin "temel hak ve hürriyetlerin yasayla sinırlandırtlabilece ğ $i^{\prime \prime}$ yönündeki anayasal ilkeye aykırı olduğu ileri sürülebilecektir. Bu noktada RTÜK'ün duizenleme yetkisi üzerinde durmak gerekir. RTÜK bu yetkiyi nereden almaktadır? Anayasanın 124. maddesi;

"... kamu tüzel kişileri, kendi görev alanların ilgilendiren kanunların ve tïzüklerin uygulanmasın sağlamak üzere ve bumlara aykurı olmamak şarnyla, yönetmelikler çıkarabilirler"

hükmünü havidir. Dolayısıyla bir kamu tüzel kişisi olarak RTÜK, görev alanı ile ilgili yönetmelikler çıkarmaya Anayasa ile yetkilendirilmiştir denilebilir. RTÜK'ün kuruluş amacı, radyo televizyon alanını düzenlemek olarak 3984 s. Kanunun 5. maddesinde açıkça bildirildiğinden bu yetkinin sadece Anayasa ile zımnen tanınmadığı ayrıca Kanunla da verildiği açıktır. Zaten RTÜK'ün asli varlık nedeni de budur.

RTÜK kendisine 3984 s. Kanunla açıkça diizenleme yapması yetkisi verilmeyen alanlarda da düzenleme yapabilir mi? Anayasanın yukarıda anılan ilgili hüikmü kamu tüzel kişilerinin düzenleme yetkisi konusunda "kendi görev alanı" ve "kanun ve tïzüklerin uygulanmasın să̆lamak" şartlarını koymuştur. Bu şartlara aykırı olmaması halinde, açıkça düzenleme yapacağ1 öngörülmüş olmasa bile, düzenleme yapma yetkisine sahiptir denilebilir(YILMAZ : 170). Çünkü RTÜK'de diğer kamu tïzel kişileri gibi faaliyette bulunduğu konularda yönetmelik çıkarılması gerekmeyen bazı 
konularda yönetmelik benzeri düzenleyici işlemlerle takdir yetkisine dayalı olarak düzenlemeler yapabilir.

\section{Tahsis İşlevine İlişkin Sorunlar}

RTÜK'ün tahsis ettiği kanal ve frekansların niteliği nedir'? Bu konuda kanal ve frekansların kamu malı olduğu ve olmadığı yönünde iki zit görüş vardır (YILMAZ: 172-5) ${ }^{13}$. Sonuç olarak $3984 \mathrm{~s}$. Kanunun, tahsis edilecek olan kanal ve frekansın mülkiyetinin değil de sadece belli süreyle kullanımını tahsisini düzenlemiş olması da destek altndığında, tahsis edilecek kanal ve frekanslarin kamu malı sayılması datha akilcı gelmektedir(YILMAZ: 175). Bu nedenle yaplacak tahsis kamu malmun belli şartlarla özel hukuk kişilerine tahsisi olacak ve idare hukukunun genel ilkelerine tabi olacaktır.

\section{Denetim İşlevine İliş̧in Sorunlar}

RTÜK'ün denetim yetkisi üç bölümde incelenmesi mümkün olan başlıklardan oluşmaktadır. Bunlar; (i) RTÜK'ün yayın kuruluşları üzerindeki yapısal denetim yetkileri, (ii) yayınlar üzerindeki denetim yetkisi ve (iii) seçim dönemindeki denetim yetkisidir.

RTÜK, yayın kuruluşları üzerindeki yapısal denetim yetkisini $3984 \mathrm{~s}$. Kanunun 30. maddesinde kendisine tanman düzenleme yetkisine dayanarak çıkardığı bir yönetmelik (R.G. 16.3.1995, S. 22229) çerçevesinde kullanmaktadur. Bu yönetmelikteki düzenlemeler daha çok özel radyo televizyon kuruluşların mülkiyeti konusunda bilgi edinmeye ilişkindir(YILMAZ: 185).

RTÜK'ün yaymlar üzerindeki denetim yetkisi ise 3984 s. Kanunun hükümleri gereği sadece bu kanuna göre değil Türkiye'nin bu konularda taraf olduğu uluslararası sözleşme hükümleri de göz önünde bulundurularak yapılacaktır. Bu nedenle uyulacak esasların belirlenmesi konusunda söz konusu belgelerde dikkate alınacaktır.

RTÜK'un seçim dönemlerindeki denetimi ile seçimlere ilişkin yayınların denetimi kastedilmektedir. Yoksa seçimlerle ilgisi olmayan yayınlar tıpkı normal dönemdeki gibi denetime tabi olacaktır. Seçinlere ilişkin yayınlar ise $3984 \mathrm{~s}$. Kanunun 27. maddesi gereği RTÜK tarafından, Yüksek Seçim Kurulu kararları doğrultusunda yapılacaktır. Nitekim bu

\footnotetext{
${ }^{13}$ Bu konuda ayrıca bkz. Yıldızhan YAYLA, "Kamu Malımm Çăgdaş Tammm", In Hukuk Araşctumalası. C.7.S. 1-3. Yıl 1992-3, s. 14-5.
} 
hüküm seçimlerin düzeninin ve dürüstlüğünün sağlanması görevini ve buna ilişkin yetkileri Yüksek Seçim Kuruluna veren Anayasanın 79. maddesindeki düzenleme ile de örtüşmektedir.

\section{Yaptırım Uygulama İşlevine İlişkin Sorunlar}

RTÜK'ün görev ve yetkileri ile ilgili belki de en sorunlu konu onun yaptırım uygulama yetkisi, bu yetkinin içeriği ve niteliğidir. Biz burada yaptırımların içeriği hakkında kısa açıklamalardan sonra niteliği ve Anayasa'ya uygunluğu sorunları üzerinde durmak istiyoruz.

3984 s. Kanunun 8 (1) maddesinde RTÜK'ün müeyyide uygulamaya yetkili olduğu belirlenmiş ve bu müeyyideler ve içerikleri Kanunun $4756 \mathrm{~s}$. Kanunla değişik 33. maddesinde uyarı, para cezası, durdurma ve iptal başlığı altında açıklığa kavuşturulmuştur. Şu halde ïst kurul, dört tip müeyyide uygulayabilecektir; (i) yayın kuruluşunun uyarılması, (ii)yayın kuruluşlarına para cezası kesilmesi, (iii)yayın izninin geçici olarak durdurulması ve (iv)yayın izninin iptali.

Kanunun 33. maddesine göre RTÜK, özel radyo ve televizyon kuruluşlarını; (i) öngördükleri yükümlülüklerini yerine getirmemeleri, (ii) izin şartların ihlal etmeleri ve (iii) yayın ilkelerine ve Kanunda belirtilen diğer esaslara aykırı yayın yapmaları halinde uyanı ve aynı yayın kuşağında açık şekilde özür dilemelerini ister. Burada öngörïlmüş olan yükümlülüklerin kim tarafından öngörüldügüu konusunda bir soru akla gelmektedir. Kanunun 18. maddesinde ulusal yayın izni alan radyo televizyonlarm "haftada asgari 80 saat yaym yapmak ve Tiurkiye alanintn $\% 70$ 'ine yayınlarını en geç ikinci yılın sonunda ulaştırmak" durumunda oldukları belirlenmiştir. Dolayısıyla öngörülen yükümlülüikler Kanun tarafından belirlenmiş̧ir.

Durdurma müeyyidesi ise uyarrya neden olmuş "falebe uyulmaması" ve "ihlalin tekrarlanmasi" halinde uygulanabilecektir.

Kanunun düzenlediği üçüncü müeyyide ise para cezası kesilmesidir. Bu cezaya uyarıya neden olmuş aykırılığın tekrarı halinde başvurulacaktır. Kesilecek para cezası ulusal ve yerel yayın yapan kuruluşlar açısından farklı olduğ gibi yerel yayın yapan kuruluşlarda kendi içinde dört kademede ele alınmıştır.

Kanunun düzenlediği son müeyyide ise iptal'dir. 33. maddenin beşinci fikrası gereğince; (i) Kanunun 4. maddesinin 2. fikrasındaki a, b ve c bentlerindeki ilkelere aykırı yayı yapılması halinde uyarı yapılmadan yayin 
durdurulur ve uyarlya neden olmuş "ihlalin tekrarlanmas" halinde yaym durdurulur ve yayon lisans izni iptal edilir (ii) "yayn isnimi verilmesi (alınmasi) için gerekli sartlardanhen birinin kaybedilmesi" ve/veya (iii) "yayın izni jçin gerekli "şartlarm uygunluğunu(n) hile ile elde od(ilmesi)" durumlarnnda yayın lisans izninin iptali müeyyidesi uygulanacaktır.

3984 s. Kanunun 33. maddesinde öngörülmemiş olmasına rağmen lisans izninin yenilenmemesinin de bir müeyyide olduğunu bclirlemek gerekir. Kanunun 8 (b) fikrası uyarmca yaym izni ve lisans vermek yetkisi ile donatılan RTÜK'ün bu izin ve lisansın kullanılacağı alan olan kanal ve frekansları talhsis etmesine ilişkin esaslar 17. maddede düzenleumiştir. Buıa göre; "tahsis siiresi beş yll aşama"yacak ve tahsis (8. madde uyarıncil) hakkaniyet ilkelerine uygun yapilacaktır. Yani mutlaka beş yll olmasi da gerekmemektedir. Dolayısıyla RTÜK yukarida sayılan yaptımlarm ötesinde lisans vermeme yetkisini de elinde bulundurmaktadır. Başka bir deyişle bu konuda geniş bir takdir yetkisi vardır. Bu sonuç tisuns vermeye yetkili makamm vermemeye de yetkili olması anlamına gelen idari işlemlerde yetki ve usulde paralellik ilkesinin de doğal sonucudur. Açkçai görüleceği üzere bu yetki sayılan yaptırm yetkilerinden çok daha ăğı bir müeyyideye dönuiş̧ebilmektedir(YIL.MAZ: 208).

RTÜK tarafından uygulanacak yaptırımların niteliğgi üzerinde durabilmek için RTUKK ile özel radyo televizyon kuruluşlar arasındaki ilişkinin niteliğini ve idari yâptrrm uygulanmasına ilişkiı ilkeleri belirlememiz gerekmektedir.

Özel hukuk kişileri radyo televizyon alanında izin sistemi çerçevesinde faaliyette bulunmaktadırlar. Dolayısıyla RTÜK ile özel kişiler irasında "hiyerarşi" bağg yoktur. Buna bağlı olarak da RTUK'ün yatptınm uygulama yetkisi disipin hukuku çerçevesinde de gerlendirilemez.

RTÜK'ün kolluk yetkilerini haiz bir kamu kurumu olduğunu daha önceden belirlemiştik. Buradaki kolluk yetkisi genel kolluk yetkisinden farklı, özel kolluk (ya da hizmet kolluğu) yetkisidir. Çünkü kamu dïzeninden farklı özel bir alanın düzeni sağlamaktadır(YILMAZ: 190-1). Nitekim RTǗ'ün düzenleyici işlem yapması ile Kanun ve yapılan düzenleyici işlemler doğrultusunda bireysel işlemler tesisi suretiyle radyo televizyon yayıncıltğı alanm idare etmesi bunun genel idari koiluktan farklı. özel (hatta hizmete özgii) bir kolluk faaliyeti olduğunu ortaya koymaktadır. Ancak bu alanda faaliyet gösteren özel kişilerin faaliyetlerinin serbest ticari faaliyet olduğu da söylenemez. İlk bakışta gerekçe olarak 3984 s. Kanunun 4. maddesinde yer alan "Radyo televizyon yomlar kamu hizmeti anlayss içerisinde ... Yaphlo" hükmü ileri sürülebilir. Ancak bu hükmün satdece etik 
bir yuiküm getirdiği faaliyetin kamu hizmeti sayılamayacağı da savunulabilir. Bununla birlikte Kanunun genel sistematiğ ve RTÜK'e tanman yetkiler incelendiğinde faaliyetin kanun koyucu tarafından, tam (pür) bir serbest ticaret faaliyeti olarak anlaşılmadı̆̆ı görülmektedir. Nitekim Özel radyo televizyon kuruluşlarına getirilen;

m. 31- "belli oran ve saatlerde eğitim, kültür, Türk Halk ve Türk Sanat müziği programlarina yer vermek zorunda olmak"

m. 8 (p)- "Haberlere, spor programlarina ve reklamlara ayrilmts zamanlar harif olmak iuzere, yaymciların, yayın zamanlarinin en az yarısının yerli yapımlara ayrılmasinı sağlamak

m. 8 (s)-Demokratik kurallar çerçevesinde, kamunun siyaset, eğitim ve kultiürel alanlardaki beklentilerine cevap verecek sekilde, demokratik gruplar ve siyasi partiler arasındaki firsat eşitliginin sağlanmasına (çalışmak)

m. $8(u)$-Türk müzik sektörünün gelişimine katkıda bulunmak ilkesinden hareketle ....

yayın yapma yükümlülükleri konunun, sadece serbest ticari faaliyet olarak değil aynı zamanda kamu hizmeti olarak görüldügü savını desteklemektedir(YILMAZ: 191 ve 215). Bu nedenle RTÜK'ün esas işlevi belirli özel bir alana ilişkin kolluk yetkilerini kullanma olarak kabul edilmekte ve ayrıca alanın aktörlerinin faaliyetleri de pür ticari faaliyet olarak dey̧il kamu hizmeti özelliği de gösteren bir faaliyet olarak anlaşılmaktadır. Nitekim geçerli rejimin de izin sistemi ile kamu hizmetinin özel kuruluşlara gördürülmesi olduğu bu noktadan çıkmaktadır.

İster radyo televizyon alanında olsun ister başka bir alanda olsun söz konusu olan, idari fonksiyon ifası içerisinde yaptırım uygulama olduğunda, bunun idari yaptırımlar hakkındaki genel ilkelere tabi olması gerekir. İdari yaptırımların uygulanmasında uyulacak esasa ilişkin ilkelerden olarak; (i) kanunilik, (ii) orantılılık ve (iii) geriye yürümezlik ilkeleri sayılmaktadır(GÖZÜBÜYÜK- TAN: 495).

Bilindiği üzere hukuk devleti ilkesinin temel gereklerinden biri "suç ve cezaların kanuniliği"dir. Anayasa Mahkemesi bu ilkeyi ve gereklerini ;

"ilke(si)nin esast, yasa tarafindan suçun yani ne gibi eylemlerin yasaklandığtnın hiçbir şüpheye yer verilmeyecek biçimde belirtilmesinden ve 
buna göre cezanin yasayla belirlenmesinden ibarettir. Kişinin yasak eylemleri ve bunarn cezalarin önceden bilmesi gerekir.

Tïm bunlar suç ve cezaların yalnzca yasayla konulup kaldırtmasmm yeterli olmadığt, konulan kuralın açık anlaşılle ve sinırlarmm belirli olması gerektiği sonucunt doğırmaktadır.

Cezanın yasallı̆̆ ilkesi, bir suça uygulanacak yaptırm tïrlerinin, ölçülerinin. hangi stmular içinde uvgulanacağının, ...yasakoyucu tarafmindan kurala bağlanmasinı zorunlu kllnaktadır."( AYM Kararı, E. 1993/5, K. 1993/25, K.T: 6.7.1993, AMKD S. 31, C. 1, s. 225)

şeklinde belirlemiştir. Dolayısıyla RTÜK'ün yaptırım uygulama yetkisinin de bu çerçevede değerlendirilmesi gerekecektir. İlkenin gereklerinden biri olan yaptırımların Kanun ile öngörülmiş̧ bulunması, 3984 s. Kanun için gerçekleşmiş ve yaptırımlar tek tek belirlenmiştir. Ancak bu yaptırımların uygulanacağı eylemlerin belirsiz olduğu ve bu durumun Anayasanın 38. maddesine aykırılık teşkil ettiği ileri sürülebilmektedir(HAFIZOĞULLARI: 26).

İdarenin düzenleyici işlemleri ile yaptırım konulması sorununa gelince: Idarenin düzenleyici işlemleriyle, örneğin yönetmeliklerle, idari ceza tayin etmesi mümkündür(GUNDAY: 2002: 202) ${ }^{14}$. Ancak Anayasa Mahkemesinin verdiğ

"Yönetim(idare), yönetim iliskisi nedeniyle yönetilenler hakkunda yapturm uygulama yetkisine sahiptir. ... (Ancak) (Y)önetion, yasal belirleme ve dayanak olmadan herhangi bir davrantşn yaptırm gerektirdiğini takdir edip kendi yetkisiyle bu konuda kural koyamaz" (AYM Karan. E. 1987/16. K. 1988/8. K.T. 19.4.1988, AMKD S. 24, s. 109).

yönündeki kararı dikkate alındtğında idarenin dïzenleyici işlemleriyle ancak kanunla konulmuş bulunan cezayı ve kendisine ceza tertip edilen eylemleri sayma vb. yollarla açıklığa kavuşturacağı savunulabilir. Nitekim Türk Ceza Hukukunda "açık ceza normu"na yet verilmiş olması da bt: görüşümüzüi destekler niteliktedir(GÖZÜBÜYÜK-TAN: 495).

14 NALBANT ise bu görüşe karşı çımaktadır. Ona göre; "görsel işitsel alanda üst kurula Üst Kurula tanman yaphrım yetkisinin, diğer idari yapurım rejiminden aym bir statisimïn bulummast gerekriği söylenebilir. Çinkii bu yapurtmlar doğrudan bir temel hakka, ifade özgürlüğüe ilişkindir.

Yaptminlar ... görsel işitsel iletişin özgürlïgünden üstün temet haklarm korummasm amaçlayan işlemler nitcliğindedir". (NALBANT: 124-5). 
Sonuç olarak RTÜK özelinde konuya baktığımızda; belli bir hizmet alanını düzenlemek ve denetlemek göreviyle donatılan RTÜK, kendi kuruluş Kanununda yer alan suç ve cezalar için düzenleyici işlemlerle, yukarıda belirlediğimiz nitelikte tasarruflarda bulunabilecek ancak Kanunda hiç öngörülmemiş bulunan bir eylemi suç olarak niteleyemeyecek ve ayrıca öngörülmemiş bulunan cezaları da tertip edemeyecektir.

RTÜK'ün idari yaptırım uygulayabilme yetkisi Anayasa'nı 38. maddesi hükmï gereği, "kişi hürriyetinin stmırlandırlmast sonucunu doğur"amayacak, görsel işitsel iletişim özgürliŭğü ile Anayasa'da sayllan diğer özgürlüklerin alanını genişletici nitelikte olabilecek fakat idari yaptırımların uygulanmasına ilişkin esasa ve usule ilişkin ilkelere de uyacaktır(NALBANT : 125 ).

Idari yaptırımların esasına ilişkin ilkelerden bir diğeri olan geriye yürümezlik, suç ve cezayı düzenleyen kuralların konuldukları tarihten önceki olaylara uygulanamayacağı şeklinde anlaşılır. Ceza hukukunun bu ilkesi idari yaptırımlar için de geçerlidir(GÖZÜBÜYÜK- TAN :496).

Orantılılık ilkesi, suç ile verilen ceza arasında adalet ve hakkaniyet ilkelerine uygun bir nispet bulunması anlamına gelir. Idari yaptırımlar alanında da bu ilke geçerlidir(ÖZAY: 59). Dolayısıyla, RTÜK kendisine kanunda verilmiş bulunan ve ayrıntıları düzenleyici işlemlerle belirlenmesi mümkün olan yaptırım uygulama yetkisini, eylem ile müeyyide arasında oran gözeterek kullanacaktır. Nitekim 3984 s. Kanunun 33. maddesinde de bu hususun altı çizilmiştir(YILMAZ: 194). Kanun koyucu orada izin uygulamasının bir ila on iki kez arasında durdurulabileceğini düzenlerken ölçillülük ilkesine uyulmasını da emretmiştir. Ayrıca 3984 s. Kanun 4756 s. Kanunla değişmeden önce yapılan uyarıda "gerçekleşen ihlalin ağırliğıntn ( da) bildirilmesini" emretmişti. Bu yükümlülük bugünkü düzenlemede açıkça yer almıyor olsa bile idarenin açıklığı ve şeffaflığı ilkesi gereği bu ilkeye uyulmasının gerekliliği de kabul edilmelidir. Orantıltk ilkesi bakımından bir diğer nokta $3984 \mathrm{~s}$. Kanunda $4756 \mathrm{~s}$. Kanunla yapılan değişiklikten sonra ortaya çıkmıştır. Nitekim Sözü geçen. kanunun 16. maddesi ile 3984 s. Kanunun değjştirilen 33. maddesine göre RTÜK, çeşitli ihlaller durumunda, ulusal televizyon kuruluşlarına 125 milyardan 250 milyara kadar; yerel, bölgesel ve kablo ortamında yayın yapan televizyon kuruluşlarına yayın alanını kıstas alan çeşitli durumlarda 60 milyardan 100 milyara kadar, 30 milyardan 60 milyara kadar, 20 milyardan 40 milyara kadar, 5 milyardan 10 milyara kadar idari para cezası verme yetkisi ile donatılmı̧̧ır. Bu cezalar aynı durumlarda radyo kuruluşları için yarısı oranında uygulanabilecektir. $\mathrm{Bu}$ cezaların her birinin belirlendiği fikralarda da Kanun orantılık ilkesine 
özellikle atıf yapmıştır. Ancak bu cezaların belirlenmesinde RTÜK'e tanınan takdir yetkisinin sınırlarının çok geniş olduğunun altını da çizmek gerekir ${ }^{15}$

Bunlara ek olarak RTÜK'ün yaptırım uygulama yetkisini kullanırken idari işlemlerin yapılması usulü kurallarından kabul edilen gerekçeli olma ilkesinin burada da özenle uygulanmasını kabul etmek hukuk devleti açısından çok önemlidir. Şöyle ki: idarenin bütün işlemleri gerekçefidir ancak gerekçe işlemin ilgilisine değil dava açılırsa yargı organlarına bildirilir(GUNDAY : $2002: 133)^{16}$. Burada bu istisnaya ikincisini eklemek bizce hukuk devleti ilkesinin bir gereğidir. Çünkỉ yapılan ihlal sonucunda sadece uyarı ve/veya durdurma cezasina başvurulmamakta ihlalin tekrarı halinde dikkate alınmak üzere deyim yerindeyse bir de sicil tutulmaktadır. Tekrar halinde de çok ağır miieyyidelere başvurulabilmektedir. Öyleyse bu kadar ağır müeyyidelerle karşılaşılması olası bu gibi durumlarda gerekçenin bildirilmesi ilgililer açısından büyük önem arz edecektir. Ayrıca hukuk devletinin bir gereği olan idarenin açıklı̆̆ı ve şeffaflı̆̆ ilkeleri ile işlemlerin öngörülebilir olmaları da böylece güvence altına alınmış olacaktur(AKYILMAZ: 202).

${ }^{15}$ Nitekim daha önce değinilen ve CB tarafından açılan iptal davasının gerekçesinde de : "Bu fikrada ingörallen idari para cezalarmin tutarlarmin fok yäksek olduğt aşktır. Paru cezalan, basm ve raym dişnda bir gelir desteğine sahip olmayan ulusal ve özellikte verel ve

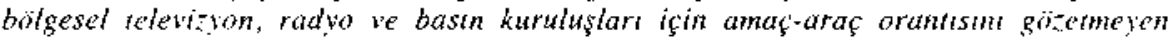

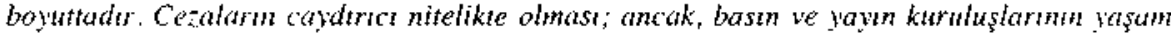
şansun ellerinden almamast gerekmektedir.

Soz konusu fikra ile getirilen para cezalarm, Anayasa'nn 26, maddesinde ver verilen haber alma özgirlïği ve 28 . maddesinde sözi edilen basin özgürlägü yoniunden son derece ağır nitelik taşıdığı ve bu maddelerle bağdaşmadı̆̆ı kuşkusużdur.

Anayusa'un 13. maddesinde, temel hak ve ögürlikklerle ilgili smirlamalarm "denokratik toplum diizeninin gerekleri"ne ve "ölçululiak ilkesi"ne aykir olamayacağ belirtilmişir.

Buna göre, hak ve ozgürlukler, ancak demokratik toplum duzeninin gereklerine uygun olarak smirlandrilabilir. Demokratik hukık devletinde, gïdülen amą̧ ne olursa olsun. stmmlanular äsimlïğïn kullaniniasin ölçusiz bicinde ortadan kaldracak diiseyde olama-.

Anayasa Mahkemesinin çȩith kararlarında da belirtildiği gibi, bir simrlama kuralmm demokratik toplum düzninin gereklerine uygun olabilmesi igin "ölçülaläk" ilkcsinin gözetilmesi amar ve simrlama "orantusınn' korunmasi gerekmektedir.

Olçilialük ilkesi, yasal düzenlemede smirlama aracmm, simirlama anacina ulaşmaya elverişi olmasim. sinrlama aractyla amact arasindaki oranın olçüsüs olmamasim anlatmaktadir.

Anlan fikra ile getirilen, ulusal, bölgesel ve yerel çerçevede hizmet veren bir şok görsel. işisel va da vash medya kuruluşınun kapanmasna neden olacak tutarlardaki para ceăalarim, hakh bir nedene dayandirmak, Anayasa'nin 13. maddesindeki "demokratik toplam düeninin gerekleri" ve "ölçulialük" ilkesigle bağdaştırmak olanakh değildir.

Bu nedenterte, maddenin ikinci fikrasi, Anayasa'nin 26., 28, ve 13. maddelerine akk olışıturmakıadı." açıklamalarına yer verilnış̧ ve hükümlerin iptalj istenmiştir. Biz de C.B'mı istem gerekçelerine ve sonuçlarına aynen katılıyoruz.

"s Bu konuda ayrıntı̀ı bilgi için bkz. Bahtiyar AK YILMAZ, Jdari İşlemin Y'apılış Usulü. Yetkin Yay. . Ankara, 2000, s. $199 \mathrm{vd.}$ 
Burada idari yaptırımlar konusunda gerçekleşecek tekerrür konusuna da değinmek istiyoruz. Ceza mahkumiyeti gerçekleştikten sonra kişinin tekrar suç işlemesi hali olarak kabul edilen tekerrür, işlenen suç açısından özel ve genel; suç işlemenin belli bir süreye tabi tutulup tutulmaması açısından da müddetli ve müddetsiz olmak üzere iki temelde ikiye ayrılmaktadır. Işsenen ikinci suçun ilki ile aynı olması haline özel tekerrür; farklı olması haline de genel tekerrür gerçekleşirken; suç işlemenin belli bir süre içerisinde gerçekleşmesi öngörülmüşse müddetli tekerrür, bu konuda süre öngörülmemişse müddetsiz tekerrür gerçekleşir.

3984 s. Kanunun 4756 s. Kanunla değişik 33 . maddesinde uyarı yapılmasına neden olan "ihlalin tekrarlanmast halinde" değişik oranlarda para cezası verileceği hükme bağlanmıştır. Burada hem müiddetsiz hem de genel tekerrür vardır. Çünkü tekerrür için ne süre bildirilmiştir ne de ihlali gereken hükmün aynı olması konusunda bir açıklı̆̆a yer verilmiştir(YILMAZ : 197).

$3984 \mathrm{~s}$. Kanunun $4756 \mathrm{~s}$. Kanunla değişik 33. maddesindeki bu genel ve müddetsiz tekerrüre bağlı olarak verilecek para cezasına esas ihlalin "ihlal tarihinden itibaren takip eden bir yil içinde tekrarı halinde" para cezaları yüzde elli oranında artırılarak verilecektir. Söz konusu bu ikinci ihlalin dışında uyarı veya yayın durdurma cezasına neden olan "ihlalin yapildı $\breve{g}_{2}$ tarihten itibaren bir yl içinde ü̧̧üncü kez tekrarı halinde ihlalin ağırlığına göre izin uygulaması bir yla kadar geçici olarak durdurulur". Burada ise her iki durumda da müddetli ancak genel tekerrür söz konusudur.

Dördüncü maddenin ikinci fikrasının $\mathrm{a}, \mathrm{b}$ ve $\mathrm{c}$ bentlerindeki ilkelere aykırı yayın yaprlması halinde ise uyar1 yapılmadan yayın durduruluyordu. $\mathrm{Bu}$ "ihlalin tekrart halinde ise yaym süresiz olarak durdurulur ve yaym lisan izni iptal edilir". Burada da görüleceği üzere müddetsiz ve genel tekerrür söz konusudur. Çünkư ilk ihlal a bendinin ihlali ikincisi ise $b$ bendinin ihlali olması durumunda durdurma ve iptal müeyyidelerine başvurulabilecektir.

İdari yaptırım uygulanmasının şekle ilişkin koşullarından en önemlisi savunma hakkıdır. Aslında ceza hukukunun en temel ilkelerinden olan ilke, savunması alınmadan kimseye ceza tertip edilemeyeceği mantığının ürünüudür. Ceza hukukunun bu ilkesi idari yaptırımlar hakkında da geçerlidir. Nitekim üyesi bulundugumuz ve yargı organı olan Avrupa İnsan Hakları Mahkemesi'nin zorunlu yargı yetkisini kabul ettiğimiz bir Hükümetlerarası uluslararası organizasyon olan Avrupa Konseyi'nin insan haklarının geliştirilip güçlendirilmesi(promotion) işleviyle uğraşan organı olan Bakanlar Konseyi, 1977 yılında aldığı; "Bireyin Idari Işlemler Karşısında Koruntması" tavsiye kararında da bu hususu vurgulamıştır. Buna göre; 
"Haklarm, çikarlarm zedeler nitelikteki her idari işleme karşı ilgili, olay ve görüşler ône sürebilir ve gerekiyorsa kant ve araçlarına başıurabilir. Bunlar idarece göz önünde tutulur. Her olayn özelliğine göre, ilgiliye? savunmast için aygun bir süre verilir"( Nakleden GÖZÜBÜYÜK- TAN : 496).

RTÜK'ün kuruluş kanununda yer alan yaptırım uygulama yetkisinin Anayasa'ya uygunluğu bir sorun olmuş ve bu iddia dava olarak AYM'nin önüne de gelmiştir. Başvuruda, söz konusu müeyyidelerin haberleşme özgürlügưunün bìr parçasını oluşturan basın özgürlügüünü düzenleyen Anayasanm 26. ve 27. maddelerindeki "ancak hakim karar ile sınırlandırlabilme" ilkesine aykırılığı savunulmuştur. Nitekim 33. maddenin bu yetkiyi ust kurula verdiği vurgulanmıştır. Ayrıca RTÜK'ün yetkileri arasında sayılan "bir yula kadar geçici olarak durdurma" ve "yayn izninin iptali" demokratik toplum düzeninin gerekleri ile bağdaşmayacak kadar geniş bir yetki olarak sunulmuştur. Bu nedenlerle davaya konu hükmün Anayasanın $13,26,27$ ve 28 . maddelerine aykırılı̆̆ı iddia edilmiştir.

Anayasa Mahkemesi başvurudaki iddiaları değerlendirdikten sonra:

"... Yasa'da hukuka aykırliğı kabul edilen eylemlere karşı uygulanmasma izin verilen bu yaptirmlar idari niteliktedir.

... (i)darenin bir yargı kararna gerek olmaksızm yasalarm aģ $k_{\xi} a$ verdiği yetkiye dayanarak Idare Hukukuna özgü yöntemlerle, doğrudan doğruya bir işloni ile uyguladığt yaptırımlarla verdiği cezalara 'idari yaptirm' denilmektedir.

... (Anayasanın 38. maddesi dikkate alınınca) Dava konusu yaptirmda idarenin yetki alam içindeki yapturtmlardan biridir.

33. maddenin itiraz konusu ikinci fikrastyla, tekrarlanmasi durumunda, ihlalin ă̆grlı̆̆ına göre izin uygulamasının bir ytla kadar durdurulnası konusunda iist kitrul yetkili kllinmistır. Tantnan bu yetkinin, yasann kimi kurallaryla hukuka aykmrliklart kabul edilen eylemlere uygulanacak yaptırmı bunlartn ă̆ırlı̆̆ına göre kişiselleştirilmesi amactn taşmast ve idari yargı yolu ile denetlenmesi olanakh bulummast karşısmda, demokratik toplum diizeninin gerekleriyle bağdaşmayacak kadar geniş olduğu yolundaki sav yerinde görïlmemiştir (AYM kararı, E. 1996/48, K. 1996/41, K.T. 23.2.1996, AMKD S. 33 C. 1, s. 181-2). 
sonucuna varmıştır. YILMAZ, bizim de katıldığımız Anayasa Mahkemesinin görüşünü GÜRAN'dan aktardığı şu satırlarla desteklemektedir:

"... Radyo televizyon ruhsatlarınin yenilenmemesi, iptal edilmesi, bu işlemlerin istasyonun evvelki yaytn sebebiyle yaptlmıs olmasına rağmen, Anayasa'ya aykirllk taşımayan gerçek muahhar(tehir edilmiş) stnirlama saylhr. Zira, kamu hizmeti mahiyeti de taşıyan radyo televizyon yoluyla ifade hareketi, diğer klasik ifade hareketinden farkl olarak, belli bir muhteva ve fonksiyon şartina tabi tutulmustur. Bu temel fark sebebiyle, radyo ve televizyon ruhsatlartnn iptali ve yenilenmemesini, klasik ifade hareketinden değişik şekilde anlamak zorundayı. ... Bu itibarla radyo televizyon ruhsatlartnin iptali veya yenilenmemsi, istasyonun, belli muhteva ve fonksiyon şartını yerine getirmemesinin, yani sadece yaptt $\breve{g}_{l}$ ifade hareketlerinin müeyyidelendirilmesinden ibarettir"( YILMAZ: 207-8).

Bu çalışmada son olarak RTÜK'ün TRT üzerindeki yetkilerine de kısaca değinmek gerekmektedir. RTUK'ün TRT üzerinde Yönetim Kurulu üyelerinin seçimi ve kurumun yayınları izzerindeki denetim yetkisi olmak üzere iki tip yetkisi vardır.

3984 s. Kanunun 36. maddesinin daha önce Radyo ve Televizyon Kurulu'nda olan TRT Yönetim Kuruluna üye seçme görevinin RTÜK'e geçtiğine ilişkin hükmü hatırlandıktan sonra; 35. maddesinin yayınlar üzerinde RTÜK'e tanıdığı yetkiye değinmek gerekir. 35. madde TRT kurumunu diger özel radyo ve televizyonların uyacağı ilkelere tabi tutarken ihlalin yaptırımı konusunda farklılık öngörmüştür. Kanuna göre TRT, "bu kanunda öngörïlen yayın ilke ve esaslarina uygun yayın yapmakla yïkümlïdür". Bu durumun ihlali halinde kurum, RTÜK tarafundan "ihlalin niteliği ve ağırlı̆̆ (da) açıkça belirtilerek" uyarılacaktır. RTÜK yayın ilke ve esaslarınm ihlali konusunda tekerrür oluştuğuna karar verirse ya da Kanunun deyimiyle "durdurmayt gerektirecek sekilde yaytn yaptlmast durumu" oluşursa, TRT Kurumu Genel Müdürünün ve Yönetim Kurulunun görevi düşecektir. Bu yaptırım bir defa uygulanmış ve TRT kurumu Genel Müdürü ile Yönetim Kurulunun görevi RTÜK kararı üzerine düşmüştür. Açılan davalar sonucunda nihai olarak Danıştay, yapılan işlemi kanuna uygun bulmuş ve işlemin iptali istemini reddetmiştir(Ayrıntı için YILMAZ: 212-3).

\section{SONUÇ}

Bağımsız idari kurumların idare hukuku literatürüne girmesinin nedenleri arasında gösterilen, klasik idari yapılanmanın atıl kalması 
gerekçesi gerçekten de belli haklılık payları taşımaktadır. Nitekim iletişim. finans, rekabet $\mathrm{vb}$. hassas alanlar hemen bütün çağdaş dünyada bağımsız idari kưumlarm görev ve sorumluluk alanlarına dahil edilmiştir.

Bağımsız idari kurumların varlık gerekçelerinden sayılan temel hak ve özgürlükler rejiminde ortaya çıkan değişimi idarenin örgütleumesindeki anılan değişimin sonucu olarak kavramak da mümkündür. Ancak ister sebep ister sonuç olarak kabul edilsin özgürlük alanının tanımlanmasındaki değişim bağı̆msız idari kurumların karakteristiğini yansıtan bir yapılanmayı gereklilik haline getirmiştir. Işte bu nedenle özellikle iletişim alanında bağımsız jdari kurumlara ve bu arada RTÜK'e ihtiyaç duyulmuştur.

1982 Anayasasının RTÜK ile ilgilendirilen 26. ve 133. maddelerinin 1993 değişikliği öncesinde çeliştiği bilinmektedir. Nitekim 26. maddenin temel hak ve hürriyetler alanını genişletici şekilde yorumlanması 133. maddenin adaleti hakkaniyeti ïzerinde tartışmalara neden olmuştur. Bu gelişmeyi 1990'lı yıllarda yaşanan, özel radyo ve televizyonların fiili bir faaliyet alanı oluşturması tetiklemiştir. Sonuç olarak 133. maddenin değiştirilmesi ve onu takip eden $3984 \mathrm{~s}$. Kanun bizi bu günkü yasal düzene ulaştırmış̧ır.

Radyo ve televizyon alanında yaplacak bir incelemede dikkat çeken önemli hususların ilki, $3984 \mathrm{~s}$. Kanunun düzenlemesi dikkate alındığında bu alanda yürittülecek faaliyetin bir kamu hizmeti niteliği gösterdiği; ikincisi ise RTÜK'ün Türk idare sistemi içerisindeki yerinin belirlenmesinin gösterdiği özelliktir. İlk konu dikkate alındığında RTÜK'ün faaliyeti bir tip özel kolluk faaliyeti olarak belirfenmektedir. İkinci konuda ise Anayasanm amir hükümleri ve idare hukukunun bilinen ilkeleri dikkate altnarak bir sonuca varmak mümkün olmaktadır. Şöyle ki; RTÜK Anayasánın 123. maddesi uyarınca merkezden yönetim veya yerinden yönetim ilkelerinden birine tabi olmak durumundadır. Ayrıca idare hukuku ilkelerinden de idarenin bütünlüğ îi ilkesine tabi olmalıdır. Nitekim konu incelendiğinde RTÜK'ün hizmet yönünden yerinden yönetim ilkesine tabi olduğu ve ayrıca kuruluşta idare bütününe dahil olduğu ancak işleyiş yönünden idare bütününe katılmasını sağlayan araçlardan yoksun bulunduğı görülmektedir. Bu nedenlŁ 3984 s. Kanunda boşluk bulunmaktadır.

RTÜK'ün gördüğü idari fonksiyonda da çeşitli sorunlar vardır. Özel kolluk işlevini oluşturan faaliyetlerin ifası sırasmda ortaya çıkan sorunların yanı sıra RTÜK'ün kurum olarak kendisinin de denetlenmesinde çeşitlj soruntar yaşanmaktadır. Ayrıca RTÜK'ün karar organı olan kuruł üyelerinin seçiminde öngörülen farklı metodun yargı denetimine ilişkin hüküm öngöruilmemiş olması ve Danıştay'ın da denetlememe yönünde olışturduğu 
içtihat sorunları daha da artırmıştır. Bütün bu sorunların Kanunda yapılacak değişikliklerle giderilmesi gerekmektedir.

Sonuç olarak RTÜK, bağımsız idari kurum karâkteristiğini taşıyan ve iletişim sektöründe $3984 \mathrm{~s}$. Kanundan kaynaklanan özel kolluk faaliyetini yürüten bir kamu kurumudur. Ancak unutulmamalıdır ki bu alanda yürütülen faaliyet Kanundan kaynaklanan nedenlerle kamu hizmeti niteliğini de göstermektedir. Bu nedenle RTÜK'ün sayılan özel durumlar dikkate alınarak kavranılması gerekmektedir.

\section{KAYNAKÇA}

AKAD Mehmet, "Özel Radyo ve Televizyon Yasast Üzerine Karşılaşıtımalı bir Çalışma" In Ilhan Akın'a Armağan, S.3-20, İÜHF Yayinları, İstanbul, 1998.

AKYILMAZ Bahtiyar, İdari İşlemin Yapılış Usulü, Yetkin Yay. , Ankara, 2000.

DURAN Lütfi, Idare Hukuku Ders Notları, Fakülteler Matbaası, İstanbul, 1982.

DURAN Lütfi, "Türkiye'de Bağımsız Idari Otoriteler", AİD, C. 30, S. 1, Mart 1997,s. 3-10.

GİRİTLİ İsmet-AKGÜNER Tayfun - BILLGEN Pertev, İdare Hukuku, Der Yayınları, Istanbul, 2001.

GÖZLER Kemal, Anayasa Hukuku, Ekin Yayınları, Bursa, 2000.

GöZÜBÜYÜK Şeref - TAN Turgut, İdare Hukuku- Genel Esaslar, C.1,Turhan Kitabevi, Ankara, 1998.

GÜNDAY Metin, İdare Hukuku, Yenilenmiş 5. Baskı, Imaj Yayınları, Ankara, 2002.

HAFIZOĞULLARI Zeki, 3984 Sayılı Kanunda Düşünce, İnanç ve İfade Hürriyeti Kısıtlayan Hükümler ve Bir Mahkeme Kararı Üzerine Düşünceler, ABD, S. 1, Ocak 1996.

NALBANT Atilla, "Radyo ve Televizyon Üst Kurulu ve Görsel Işitsel Iletişim Özgürlügü", s.109-128, In Bağımsız İdari Otoriteler, Ibrahim KABOĞLU(Editör), Alkım Yayınları, İstanbul, 1998.

ÖZAY Illhan, Idari Yaptırımlar, İÜHF Yayınları, İstanbul, 1985.

ÖZBUDUN Ergun, Türk Anayasa Hukuku, Yetkin Yayınları, 6. Baskı, Ankara, 2000. 
ROBİLLARD Serge, Television in Europe: Regulatory Bodies, John Libbey Pub., 1995.

SABUNCU Yavuz, Anayasaya Giriş, İmaj Yayıncılık, Yenilenmiş 8. Baskı. Ankara, 2002.

TEZİÇ Erdoğan, Anayasa Hukuku, 7. Baskı, Beta Yayınları, İstanbul, 2001 .

THOMPSON Brian, Textbook on Constitutional and Administrative Law, $3^{\text {rd }}$ Ed., Blackstone Press Limited, London, 1997.

ULUSOY Ali, "Regülasyon Kurumlar hakkinda Genel Bir Değerlendirme", ABD, Yıl 2000, S. 2, s. 47-59. 3-17.

ULUSOY Ali, Bağımsız İdari Kurumlar, DD, Yı 29(1999). S. 100, s.

YAYLA Yıldızhan, "Kamu Malının Çăgdaş Tanımı", In Hukuk Araştırmaları, s. 7-17, C.7, S.1-3, Yil 1992-3.

YILMAZ Halit, Türkiye'de Radyo Televizyon Yayıncıllğının Hukuksal Düzeni, AÜSBE, Yayınlanmamı̧ Yüksek Lisans Tezi, Ankara, 1999.

WADE Sir William, Administrative Law, Oxford Univ. Press, $8^{\text {th }}$ Ed. , New York, 2000.

$\begin{array}{ll}\text { KISALTMALAR } \\ \text { ab̧̧ } & \text { Altını ben çizdim } \\ \text { ABD } & \text { Ankara Barosu Dergisi } \\ \text { AİD } & \text { Amme İdaresi Dergisi } \\ \text { AMKD } & \text { Anayasa Mahkemesi Kararlar Dergisi } \\ \text { AƯSBE } & \text { Ankara Unniversitesi Sosyal Bilimler Enstitüsü } \\ \text { AYM } & \text { Anayasa Mahkemesi } \\ \text { BİK } & \text { Băğımsız İdari Kurum } \\ \text { BİO } & \text { Bağımsız İdari Otorite } \\ \text { BK } & \text { Bakanlar Kurulu } \\ \text { C } & \text { Cilt } \\ \text { Dai. } & \text { Dairesi } \\ \text { DD } & \text { Danıştay Dergisi } \\ \text { DDK } & \text { Devlet Denetleme Kurulu } \\ \text { dp } & \text { Dipnot } \\ \text { E } & \text { Esas } \\ \text { İÜHF } & \text { İstanbul Üniversitesi Hukuk Fakültesi }\end{array}$




$\begin{array}{ll}\text { K } & \text { Karar } \\ \text { K.T. } & \text { Karar Tarihi } \\ \text { RG } & \text { Resmi Gazete } \\ \text { RTÜK } & \text { Radyo Televizyon Üst Kurulu } \\ \text { s } & \text { Sayfa } \\ \text { S } & \text { Sayı } \\ \text { TBMM } & \text { Türkiye Büyük Millet Meclisi } \\ \text { TRT } & \text { Türkiye Radyo ve Televizyon Kurumu } \\ \text { YDK } & \text { Yüksek Denetleme Kurulu }\end{array}$

